\title{
Three new interstitial species of Remaneicaris Jakobi, 1972 (Copepoda: Harpacticoida: Parastenocarididae) from Southern and Southeastern Brazil
}

\author{
Paulo H.C. Corgosinho1, Pedro Martínez Arbizu², \\ Edinaldo N. dos Santos-Silva ${ }^{3}$
}

${ }^{1,2}$ DZMB - Forschungsinstitut Senckenberg, Südstrand 44, 26382 Wilhelmshaven, Germany.

${ }^{1}$ Center Unesco/HIDROEX (International Center ror Education, Capacity Building and Applied Research in Water), Frutal (MG), Brazil.

e-mails: ${ }^{1}$ pcorgo@yahoo.com.br, ${ }^{2}$ pmartinez@senckenberg.de

${ }^{3}$ Plankton Laboratory, CPBA/INPA, Av. André Araújo, 2936 Petrópolis, 69011-970, Manaus-AM, Brazil.

email:nelson@inpa.gov.br

ABSTRACT: Three new species of the genus Remaneicaris from Southern and Southeastern Brazil are described. The new species are closely related to $R$. analuizae, R. euniceae, $R$. tageae and $R$. divae, sharing the presence of a hyaline margin on the 9 th segment of male antennule. Remaneicaris itacambirucui sp.n., $R$. insolitus sp.n. and $R$. ivoneae sp.n. differ by: number of integumental windows on the 2 nd and 5 th urosomites; ornamentation of the telson, with postopercular ornamentation shared by $R$. insolitus sp.n. and $R$. itacambirucui sp.n.; shape of the swimming leg 3 exopod and armature of the swimming leg 3 endopod, with straight exopod and unarmed endopod shared by $R$. insolitus sp.n. and $R$. ivoneae sp. n.; and morphology of the swimming leg 4 endopod with a similar condition shared by $R$. insolitus sp.n. and $R$. itacambirucui sp.n. Remaneicaris itacambirucui sp.n. seems to be closely related to $R$. ivoneae sp.n. with which it shares the presence of a hyaline inner margin on the outer spine of male's swimming leg 3. Remaneicaris insolitus sp.n. seems to be closely related to $R$. divae, sharing a continuous transversal row of spinules on the anteroventral margin of the telson. In the absence of more informative characters, the exact phylogenetic position of $R$. itacambirucui sp.n. and $R$. ivoneae sp.n. within a monophyletic group of species closely related to $R$. analuizae is difficult to determine.

KEY WORDS: Copepoda, Parastenocarididae, Remaneicaris, new species, Brazil.

\section{Три новых интерстициальных вида Remaneicaris Jakobi, 1972 (Copepoda: Harpacticoida: Parastenocarididae) из южной и юго-восточной Бразилии}

\section{П.Х.К. КоргосинХо', П. Мартинез Арбизу ${ }^{2}$, Е.Н. дос Сантос-Сильва ${ }^{3}$}

\footnotetext{
${ }^{1,2}$ DZMB - Forschungsinstitut Senckenberg, Südstrand 44, 26382 Wilhelmshaven, Germany.

${ }^{I}$ Center Unesco/HIDROEX (International Center ror Education, Capacity Building and Applied Research in Water), Frutal (MG), Brazil.

e-mails: ${ }^{1}$ pcorgo@yahoo.com.br, ${ }^{2}$ pmartinez@senckenberg.de

${ }^{3}$ Plankton Laboratory, CPBA/INPA, Av. André Araújo, 2936 Petrópolis, 69011-970, Manaus-AM, Brazil. email:nelson@inpa.gov.br
} 
РЕЗЮМЕ: Подготовлено описание трех новых видов рода Remaneicaris из южной и юго-восточной Бразилии. Новые виды наиболее близки группе видов, $R$. analuizae, $R$. euniceae, $R$. tageae и $R$. divae, характеризующихся наличием гиалинового края на 9 -м членике антеннулы самца. Remaneicaris itacambirucui sp.n., $R$. insolitus sp.n. и $R$. ivoneae sp.n. отличаются: количеством интегументных окон на 2-м и 5-м уросомитах; орнаментацией тельсона, орнаментацией постоперкулярной поверхности, свойственных $R$. insolitus sp.n. и $R$. itacambirucui sp.n.; формой экзоподита и вооружением эндоподита 3-й плавательной ноги, прямым экзоподитом и лишенным вооружения эндоподитом, характеризующих $R$. insolitus sp.n. и $R$. ivoneae sp. n.; морфологией эндоподита плавательных ног 1-4, отличительной для R. insolitus sp.n. и R. itacambirucui sp.n. Новый вид R. itacambirucui sp.n. наиболее близок R. ivoneae sp.n., с которым его объединяет наличие гиалинового края на наружном шипе 3-й плавательной ноги самца. Новый вид R. insolitus sp.n. наиболее близок R. divae; оба вида характеризуются наличием поперечного ряда шипиков, расположенного у переднего края тельсона с вентральной стороны. Точное филогенетическое положение $R$. itacambirucui sp.n. и R. ivoneae sp.n. в пределах монофилетической группы видов близких к R. analuizae определить затруднительно из-за отсутствия надежных признаков.

КЛЮЧЕВЫЕ СЛОВА: Веслоногие ракообразные, Parastenocarididae, Remaneicaris, новые виды, Бразилия.

\section{Introduction}

With 31 described species, the genus Remaneicaris Jakobi (1972) is the most diverse group of the Neotropical Parastenocarididae, occupying the most basal position within the family (Corgosinho, 2007). This genus is clearly monophyletic as demonstrated by Corgosinho and Martínez Arbizu (2005) (e.g. of autapomorphies: subdistal outer spine on the exopodite 3 of the swimming leg 4 and absence of an intercoxal plate on the leg 5), and is widely distributed, occurring from Argentina to Central America.

The genus can be divided in at least the following five more speciose monophyletic groups (Corgosinho, 2007): 1) species closely related to $R$. argentina (Noodt, 1965) (viz. $R$. jujuyensis (Noodt, 1965), $R$. drepanephora (Kiefer, 1967), R. palaciosi (Noodt, 1962), $R$. clandestina (Noodt, 1963) and R. hurdi (Jakobi et Silva, 1962); incerta sedis species $P$. ahaggarica Bozic, 1978 and R. psammae (Rouch, 1962)); 2) species closely related to $R$. analuizae Corgosinho et Martínez Arbizu, 2005 (viz.
R. divae (Noodt, 1972), R. tageae (Noodt, 1972) and $R$. euniceae Corgosinho et Martínez Arbi$\mathrm{zu}, 2005) ; 3$ ) species closely related to $R$. tridactyla Corgosinho et al., 2007 (viz. R. paratridactyla Corgosinho et al., 2007, R. paraensis (Noodt, 1963), $R$. juliae Corgosinho et al., 2007, $R$. paraguayensis (Noodt, 1963) and $R$. remanei (Noodt, 1963); incerta sedis species R. hexacantha (Kiefer, 1936)); 4) species closely related to $R$. persephone (Noodt, 1965) (viz. R. hecate (Noodt, 1965), $R$. oncophora (Noodt, 1965), $R$. pluto (Noodt, 1965), R. membranacea (Noodt, 1965 ) and $R$. rhizophora (Noodt, 1965)), and 5) species closely related to $R$. cordobaensis (Noodt, 1965) (viz. R. ciliata (Noodt, 1965), $R$. sierrae (Noodt, 1965) and $R$. sanctiludovici (Noodt, 1965)).

The geographic range of monophyletic groups within the genus Remaneicaris is not well known. This is in part due to the low number of described species and the low sampling effort in different hydrographic basins. However, some patterns can already be observed. For example, the most diverse group, a clade composed by a complex of species related 
to $R$. persephone and $R$. cordobaensis (see Table 1) seems to be endemic to Argentina. This hypothesis is supported by the current knowledge about the distribution of Remaneicaris species (viz. Kiefer, 1936; Noodt, 1962; Rouch, 1962; Noodt, 1963, 1965; Kiefer, 1967; Dussart, 1983; Corgosinho, Martínez Arbizu, 2005; Corgosinho et al., 2007a-b), which suggests that the Paraná River and the Andinean mountain range are the Eastern and Western limits for the group mentioned above. Other groups, such as the one composed by species related to $R$. tridactyla (viz. $R$. remanei (Noodt, 1963), $R$. paraguayensis (Noodt, 1963), R. paraensis (Noodt, 1963), $R$. paratridactyla Corgosinho et al., 2007 and $R$. juliae Corgosinho et al., 2007), seem to have a more widespread distribution.

Three new species of a monophyletic group comprised of $R$. analuizae and other related species are described herein. The species that compose this group have been found only in the State of Minas Gerais and Atlantic Southeastern coastal rivers. The present study extends considerably the geographic distribution of this group to the hydrographic basins of the rivers Nhundiaquara, Paraná and Jequitinhonha.

\section{Material and Methods}

The described species come from 3 different hydrographic basins in Brazil (Fig. 1): R. itacambirucui sp.n. was found in Jequitinhonha hydrographic basin (Itacambiruçu River, Grão Mogol City, Northeast of Minas Gerais State), $R$. insolitus sp.n. comes from the Paraná/Prata hydrographic basin (spring of unknown name on the city of São Pedro, São Paulo State), and $R$. ivoneae sp.n. was found in the Nhundiaquara hydrographic basin (Nhundiaquara River, Morretes City, Paraná State). Samples were taken next to the river bank using the Karaman-Chappuis method (Chappuis, 1942), washed through a $100 \mu \mathrm{m}$ mesh, stained with Bengal Rose, and fixed with $4 \%$ formalin. Animals were dissected in lactic acid and mounted on slides in glycerine. Drawings were made using a Leica DMR microscope equipped with a drawing tube and with
Normarsky interference contrast, at 400x and 1000x magnification.

Only one male of $R$. insolitus sp.n. and one male of $R$. ivoneae sp.n. were obtained and no females of any of the new species described here. Single specimens are designated in full compliance with the ICZN (1999).

The pictorial cladogram illustrated in Fig. 12 is based on the results of Corgosinho (2007) that are permanently available at the libraries of the Federal University of Amazon (UFAMBrazil), National Institute of Amazonian Researches (INPA-Brazil) and at the Monoculus library ("German Centre for Study of Marine Biodiversity“ (DZMB) - Senckenberg Institute, Wilhelmshaven, Germany). Character discussion will be exclusively based on the characters depicted on the Figure 12. The results of the formal cladistic analysis Corgosinho (2007) is being prepared for publication.

The terms furca and telson are used according to Schminke (1976). The term "thumb" refers to the outer spine of the swimming leg 3 of the males homologous to the outer spine of the first exopodite of the swimming leg 3 of the copepodite $\mathrm{V}$ and females. The term apophysis refers to the second exopodite of the swimming leg 3, which apears fused to the first exopodite in most of the species of Parastenocarididae. For details about the development of the swimming leg 3 of males and homologization of structures see Glatzel (1991). The terms seta, setules, spines and spinules are used according to Huys and Boxshall (1991). Terminology and homologization of maxillary and maxillipedal structures follow Ferrari and Ivanenko (2008). The term "Groundpattern" is used in the sense of "Grundmuster" (Ax, 1984).

When necessary, the collection of Noodt was visited for the comparison of some similar characters present within Remaneicaris and in some species not directly related to it. This collection is deposited at the DZMB (Deutsches Zentrum für Marine Biodiversitatsforschung "German Centre for Study of Marine Biodiversity"), Senckenberg Institute.

The type material is deposited in the invertebrate collection of the Instituto Nacional de 


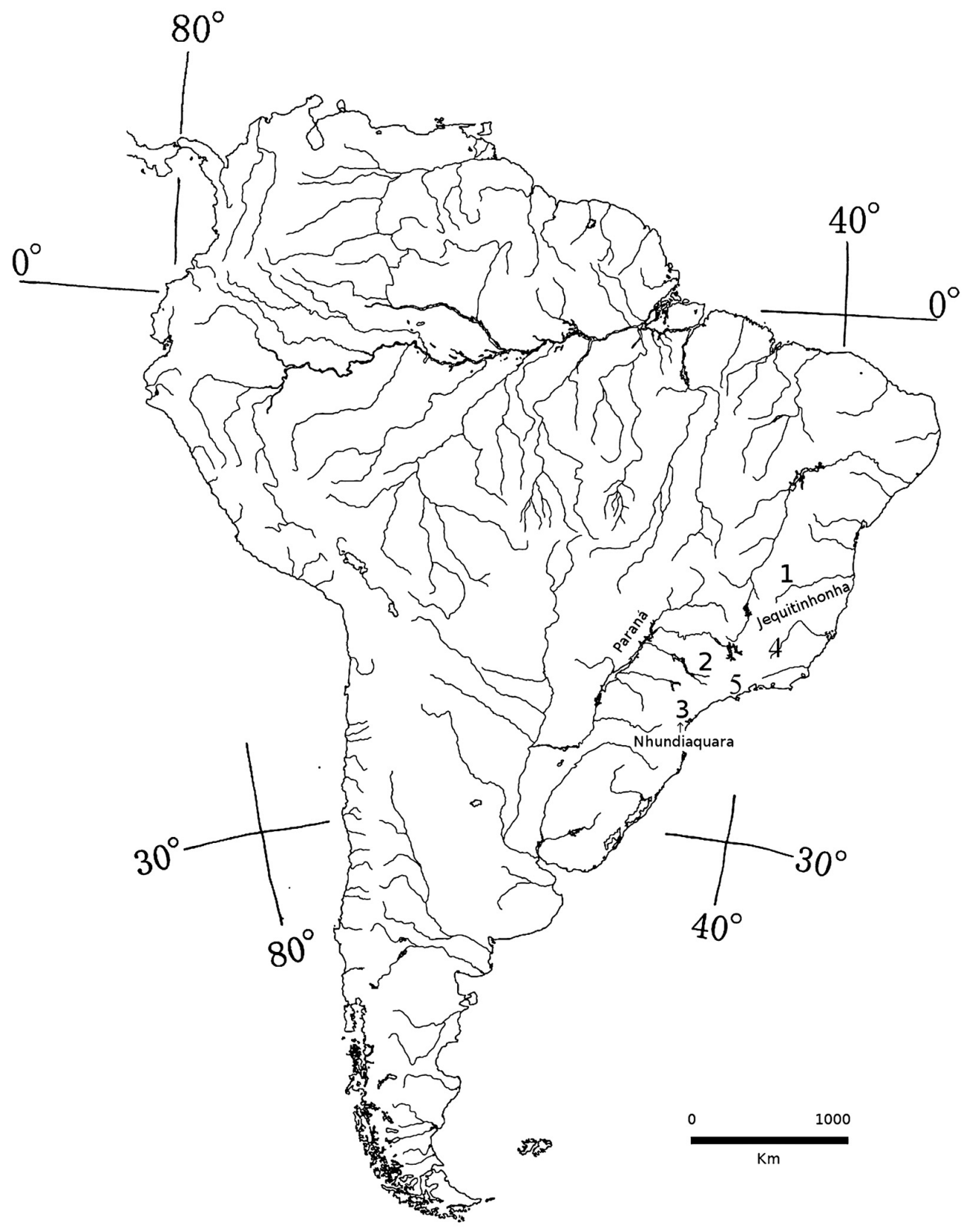

Fig. 1. Distribution in the South America of the species of the genus Remaneicaris composing the "group-C" (e.g. Table 1, Fig. 12).

$1-R$. itacambirucui sp.n.; $2-$ R. insolitus sp.n.; $3-$ R. ivoneae sp.n.; $4-R$. analuizae and R. euniceae; $5-R$. tageae and R. divae.

Рис. 1. Распространение в Южной Америке видов рода Remaneicaris, входящих в «группу С» (cp. Табл. 1, Рис. 12).

$1-R$. itacambirucui sp.n.; $2-R$. insolitus sp.n.; $3-R$. ivoneae sp.n.; $4-R$. analuizae и $R$. euniceae; $5-R$. tageae и $R$. divae. 
Pesquisas da Amazonia (INPA), Manaus, Brazil.

Abbreviations: A1 - antennule, A2 - antenna, $\mathrm{Ae}$ - aesthetasc, $\mathrm{Cph}$ - cephalothorax (includes cephalon and thoracic somites 1 and 2), DRS - distal row of spinules, enp - endopodite, exp - exopodite, Md - mandible, Mx1 - Maxillule, Mx2 - Maxilla, Mxp maxilliped or thoracopod 1, PMG - putative monophyletic groups, $\mathrm{P} 1-6-$ swimming legs 1-6 or thoracopod $2-7$, Ps $2-4-$ swimming legs somites $2-4$ or thoracopod somites $3-5$, SEM - scanning electronic microscopy, Urs1-5 - urosomites $1-5$.

\section{Systematics}

Family Parastenocarididae Chappuis, 1940 Genus Remaneicaris Jakobi, 1972

\section{Remaneicaris insolitus sp.n.}

Figs 2-5.

Holotype. One dissected male mounted on 7 slides (INPA $1451 \mathrm{a}-\mathrm{g}$ ).

Etymology. The term "insolitus", from Latin means "unusual", "uncommon", or "strange".

Type locality. The type material was sampled in a small spring located behind the «Hotel Fazenda Fonte Colina Verde», in the city of São Pedro (State of São Paulo, Brazil;22 $2^{\circ} 3^{\prime} 3.24^{\prime \prime}$; $\left.47^{\circ} 55^{\prime} 34.68^{\prime \prime} \mathrm{W}\right)$.

Male. Habitus, see Fig. 2A-B. Length 310 $\mu \mathrm{m}$ (measured from the tip of the rostrum to the distal rim of the telson). Rostrum not fused to $\mathrm{Cph}$, with a wide base and two sensilla on the tip. Cph with one dorsal integumental window (Fig. $2 \mathrm{~A}-\mathrm{B})$. With dorsal pores on Ps2 and Ps4. Urs$1-4$ as depicted. Urs-2 with a dorsolateral integumental window on each side (Fig. 2B). Urs-5 with four small integumental windows, two on each side of the segment (one dorsolateral, one lateral, Fig. 2A; 3B). For sensillae on tergites and telson see Fig. 2A-B. Telson with lateral pore and continuous ventral row of spinules on the proximal region reaching the proximal third of the segment laterally; a ventral row of up to seven spinules near the insertion of the furca
(Fig. 3A-B). Anal operculum convex, without ornamentation and flanked with two spinules on each side, on the postopercular margin (Fig 2A$\mathrm{B}$ and $3 \mathrm{~A}-\mathrm{B}$ ).

Furca proximally convex on the inner margin (Fig. 3A-B), three times as long as wide, with seven setae, all setae located on the distal third; setae I, II and III inserted at the same level of seta VII; seta IV unipinnate, shorter than seta VII; seta V longest; seta VI shortest; distoventral margin of the furca with two spinules.

A1 9-segmented (Fig. 4A), haplocer, prehensile, geniculation between segments $4-5$ and $7-8$, with a peculiar hyaline tip on the distal segment; armature formula 0/5/4/1?/5+Ae/1/2 hyaline spines +1 seta/ 1 hyaline spine +1 seta/ $7+$ acrothec (two setae + Ae).

A2 (Fig. 4B) with allobasis (slightly damaged during dissection, conferring a curved shape to it), with inner proximal row of spinules, with 1-segmented exp with one seta, free endopodal segment with a ventral hyaline frill distally, with seven setae/spines arranged as figured.

Labrum with a row of distal spinules, ventrally, with five sclerotized plates of irregular shape (Fig. 4C).

Coxal gnathobasis of Md (Fig. 4D-E) with tooth-like attenuations forming a sharp cutting edge and one seta, mandibular palp 1-segmented with one distal setae.

Praecoxal arthrite of Mx1 (Fig. 4F) with five elements (one dorsal surface seta, three clawlike pinnate spines and one slender seta), coxa with one seta, basis with two endites with one and two setae.

Basis of Mx2 (Fig. 4G) with two endites, proximal endite with two setae, distal endite with three slender setae, proximal endopodal segment drawn into a claw, distal endopodal segment with two setae.

Mxp (Fig. 4H) subchelate, composed of syncoxa, basis, 1-segmented enp and one clawlike apical seta.

P1 (Fig. 5A) coxa, with one row of spinules on the posterior side, close to outer proximal corner; basis with outer seta, three spinules on outer margin and one pore near the insertion of 

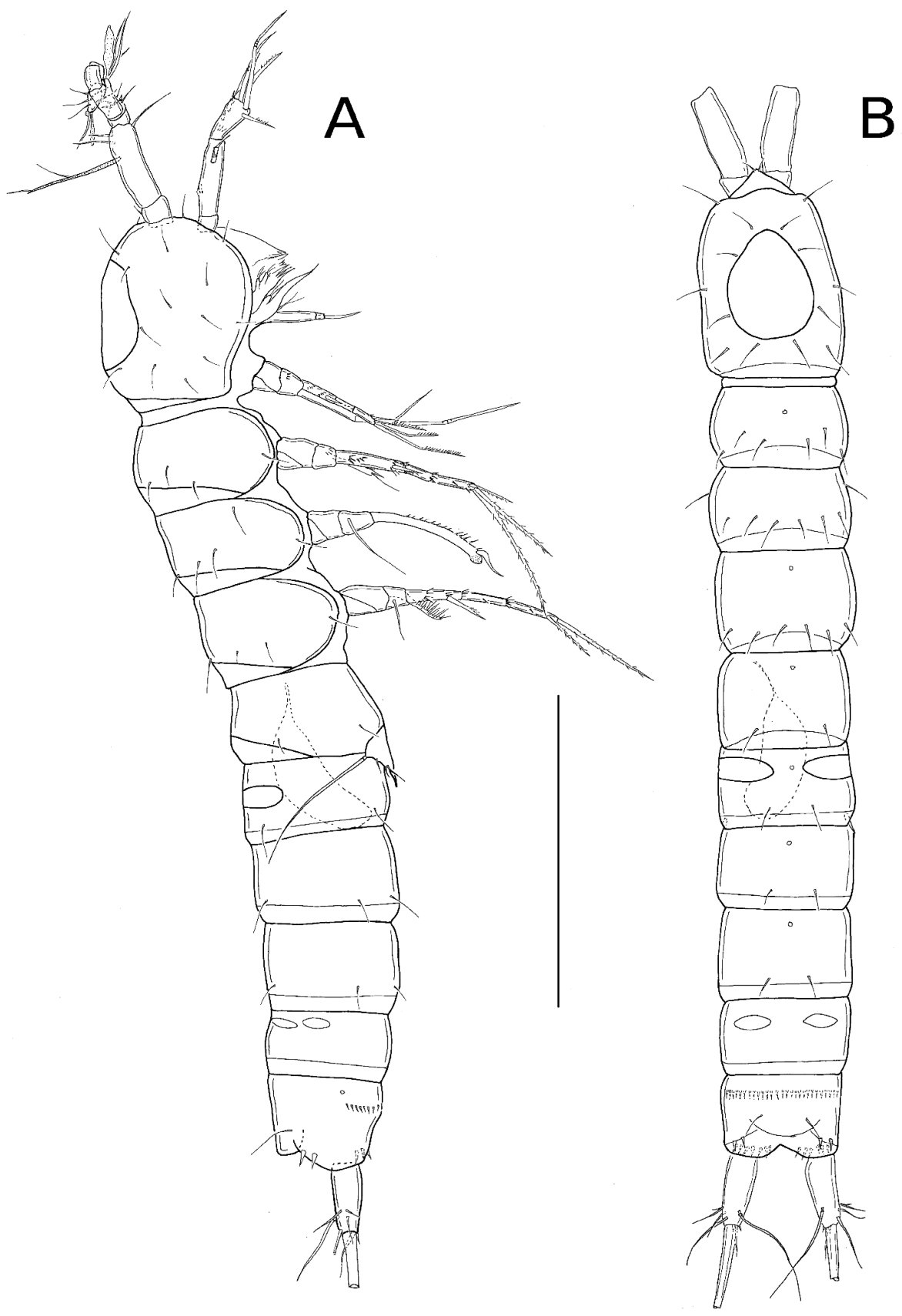

Fig. 2. Remaneicaris insolitus sp.n., male, holotype (INPA $1451 \mathrm{a}-\mathrm{g}$ ).

A - habitus, lateral; B - habitus, dorsal. Scale bar $100 \mu \mathrm{m}$.

Рис. 2. Remaneicaris insolitus sp.n., самец, голотип (INPA $1451 \mathrm{a}-\mathrm{g}$ ).

A - габитус, латеральный вид; В — габитус, дорзальный вид. Масштаб 100 мкм. 


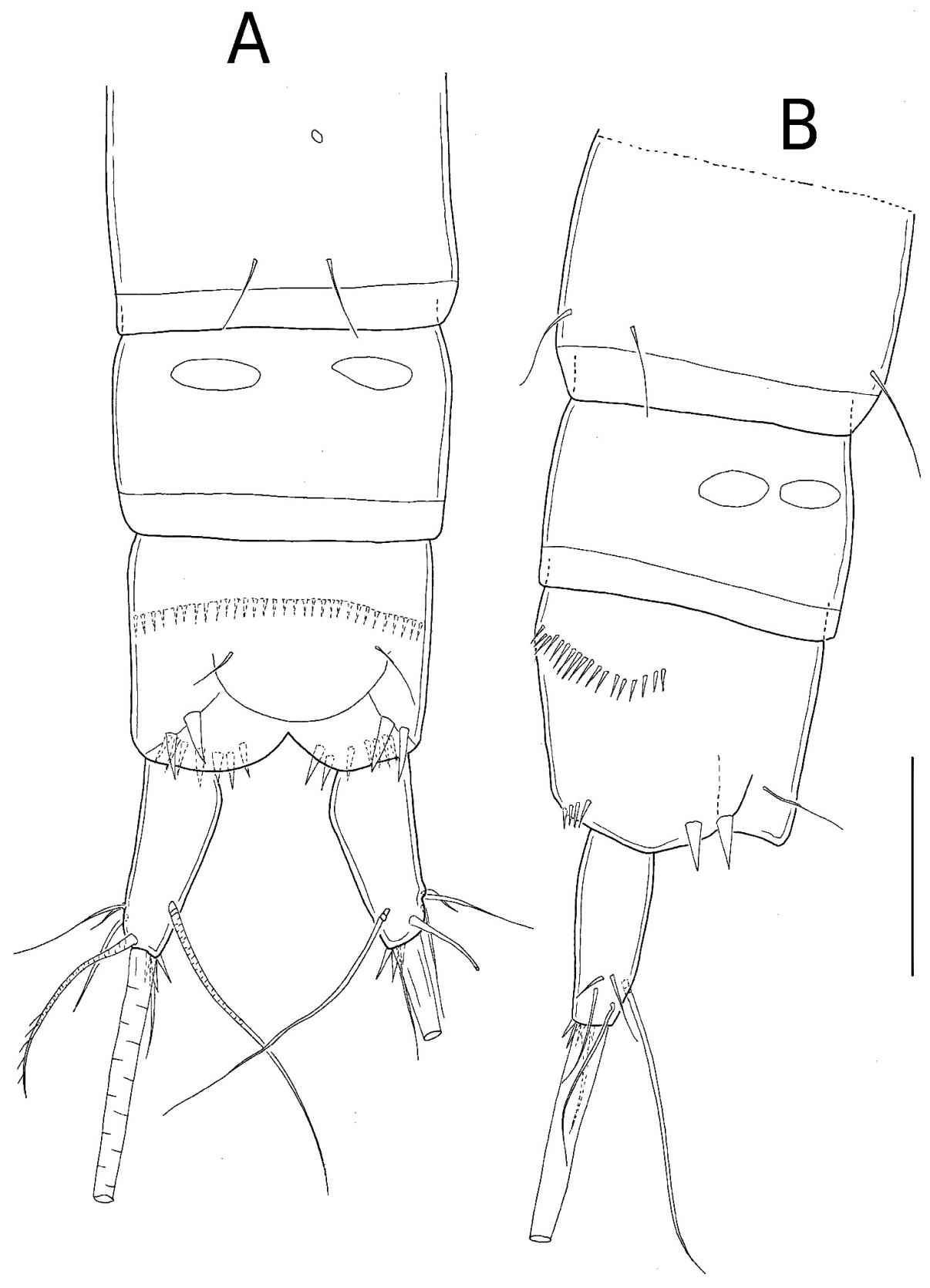

Fig. 3. Remaneicaris insolitus sp.n., male, holotype (INPA $1451 \mathrm{a}-\mathrm{g}$ ).

Telson and two previous urosomites in dorsal (A) and ventral (B) view. Scale bar $40 \mu \mathrm{m}$.

Рис. 3. Remaneicaris insolitus sp.n., самец, голотип (INPA $1451 \mathrm{a}-\mathrm{g}$ ).

Тельсон и два предыдущих уросомита, вид дорсальный (А) и вентральный (В). Масштаб 40 мкм. 


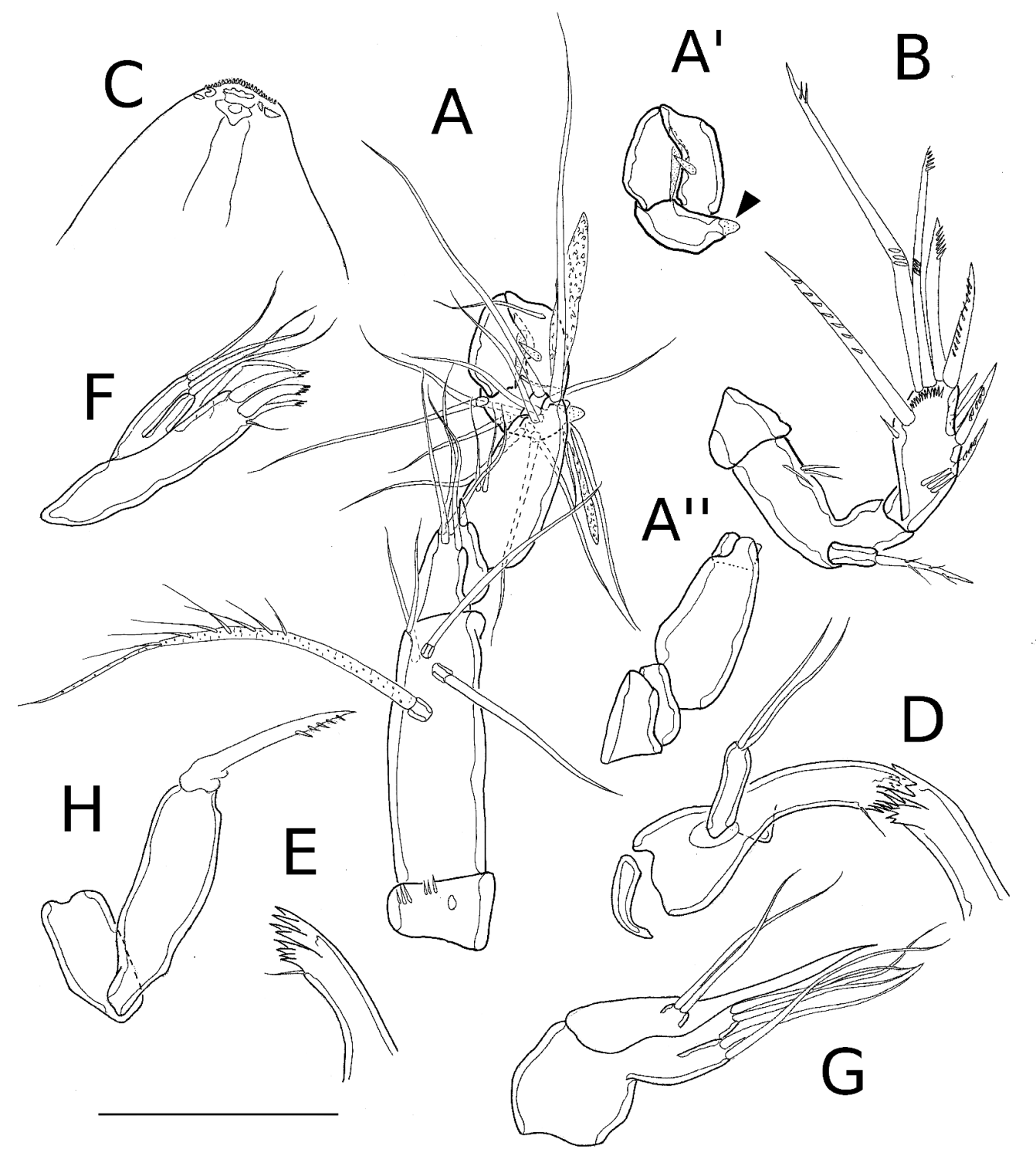

Fig. 4. Remaneicaris insolitus sp.n., male, holotype (INPA $1451 \mathrm{a}-\mathrm{g}$ ).

A - A1; A' - A1 7th-9th segments (arrow head indicates the hyaline tip of the 9th segment), A'" - A1 3rd-6th segments, B - A2; C - labrum; D-E - Md; F - Mx1; G - Mx2; H - Mxp. Scale bar $20 \mu \mathrm{m}$.

Pис. 4. Remaneicaris insolitus sp.n., самец, голотип (INPA $1451 \mathrm{a}-\mathrm{g}$ ).

A - антеннула; A' - 7-9-й членики антеннул (стрелкой отмечена гиалиновая вершина девятого членика), A" - 3-6-й членики антеннул, В — антенна; C — лабрум; D-E — мандибула; F — максиллула; G — максилла; Н - максиллипед. Масштаб 20 мкм.

the spinules; distally, with two spinules at the base of enp; inner margin with a bare protuberance; exp 3-segmented, exopodal segments ornamented as shown, exp-1 with outer spine, exp-2 unarmed, exp-3 with two outer spines and two geniculated distal setae; enp 2-segmented, endopodal segments ornamented as figured, enp1 with posterior hyaline frill (dashed lines); enp- 


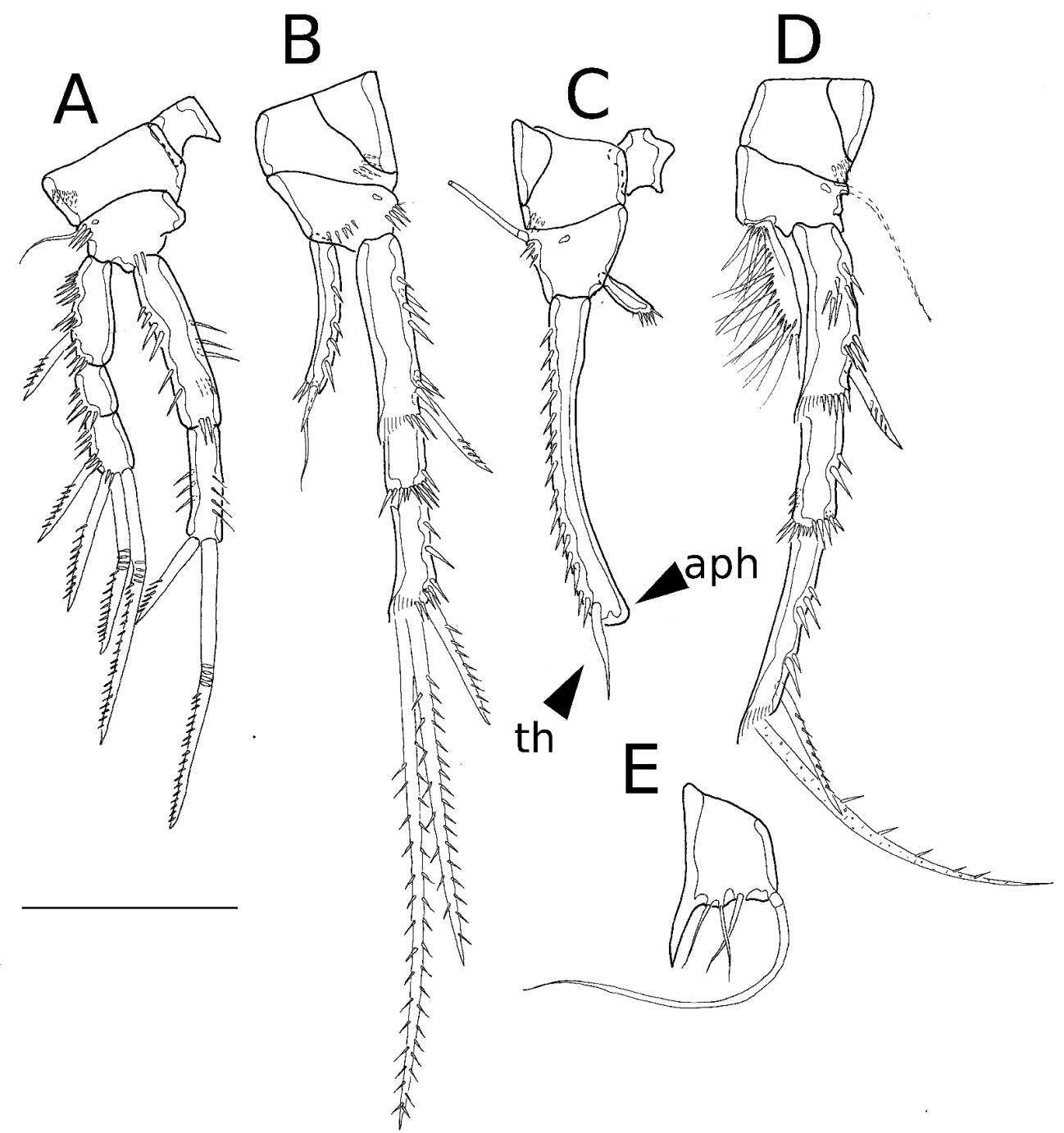

Fig. 5. Remaneicaris insolitus sp.n., male, holotype (INPA $1451 \mathrm{a}-\mathrm{g}$ ).

$\mathrm{A}-\mathrm{P} 1$; B - P2; C - P3 (arrow heads indicate the thumb (th) and the apophysis (aph)); D - P4, E - P5. Scale bar $20 \mu \mathrm{m}$.

Рис. 5. Remaneicaris insolitus sp.n., самец, голотип (INPA $1451 \mathrm{a}-\mathrm{g}$ ).

A - плавательная нога 1; В - плавательная нога 2; C - плавательная нога 3 (стрелками отмечены пальцевидный выступ (th) и апофиз (aph)); D - плавательная нога 4, Е, нога 5. Масштаб 20 мкм.

2 with one distal spine, and a geniculated distal seta, ornamented as figured.

P2 (Fig. 5B) with unarmed coxa, with one posterior row of small outer spinules; basis without outer seta, with an anterior pore close to outer margin, one row of outer spinules, and five spinules close to insertion of the enp; exp 3segmented, exopodal segments ornamented as figured, exp-1 approximately of the same size as the remaining segments combined, with a proximal row of spinules distributed in a "V" shape on the outer margin, with outer spine and a hyaline frill on the distal inner corner, exp-2 without an outer spine, exp-3 with three spines/ setae (one outer, short, unipinnate spine; one middle, long, bipinnate seta and one inner, long- 
er, bipinnate seta), with distal hyaline frill on the inner corner; enp 1-segmented with one subdistal seta, ornamented as figured.

P3 (Fig. 5C) with unarmed coxa, ornamented as shown; basis with outer seta, a row of three outer spinules close to the insertion site of the outer seta, between the outer seta and the insertion of the exp, and one anterior pore near the outer margin; enp 1-segmented, approximately $1 / 6$ the length of the exp, oval and with a row of spinules on the distal margin; exp 1-segmented, elongated, almost straight, ornamented as figured; thumb straight, inserting in an angle of $180^{\circ}$ with the main axis; apophysis short and rounded.

P4 (Fig. 5D) with unarmed coxa, with a posterior row of spinules near the outer margin; basis with outer seta (broken, not shown in the Fig. 5D) and one anterior pore near the outer margin; exp 3-segmented, ornamented as figured, exp-1 shorter than the remaining segments combined, with a proximal row of spinules distributed in a "V" shape on the outer margin, with outer spine and a hyaline frill on the distal inner corner, exp-2 without armature, with a distal row of spinules on inner margin, exp-3 with two setae/spine (one subdistal unipinnate outer spine, and a distal unipinnate seta with inner granules of uncertain nature), with a hyaline frill on the distal inner corner; enp 1-segmented, leaf-shaped, covered with numerous long spinules along the inner margin, outer margin bare.

P5 (Fig. 5E) relatively large, without intercoxal plate, almost trapezoidal, with a distal process on the inner margin, all setae inserted distally.

P6 unarmed, delicate genital aperture (similar to $R$. itacambirucui sp.n.).

\section{Remaneicaris itacambirucui sp.n.} Figs 6-8.

Holotype. One dissected male mounted on 7 slides (INPA 1452 a-g). Paratype - 1 undissected male mounted in slide (INPA 1684 b).

Etymology. The species name refers to the Itacambiruçu River, on the Basin of Jequi- tinhonha River, in the State of Minas Gerais, Brazil.

Type locality. Itacambiruçu River, State of Minas Gerais, Brazil (16 $\left.35^{\circ} 34^{\prime \prime} \mathrm{S} 42^{\circ} 55^{\prime} 15^{\prime \prime} \mathrm{W}\right)$.

Male. Habitus, see Fig. 6A-B. Length 325 $\mu \mathrm{m}$ (measured from tip of the rostrum to the distal rim of the telson). Rostrum not fused to Cph (Fig. 6B), with a wide base and two sensilla on the tip. $\mathrm{Cph}$ with one dorsal integumental window (Fig. 6B) and with dorsal pores on $\mathrm{Cph}$, Ps2 and Ps4. Urs-2 with one dorsal integumental window; Urs-5 with one lateral integumental window on each side (Fig. 6A). With dorsal pores on Urs-2 as depicted. Telson with lateral pore and a row of up to five spinules on the distal third of the segment anterior to the sensillum (Fig. 6B); operculum smooth and concave (Fig. $6 \mathrm{~B})$; postopercular zone ornamented with three spinules of unequal size (middle one larger) (Fig. $6 \mathrm{~A})$; ventrally, with a row of five spinules on each side close to the insertion of the furca (Fig. 6A).

Furca with seven setae, all of them located on the distal third (Fig. 6A-B); setae I, II and III inserted at the same level of seta VII, seta IV unipinnate (Fig. 6A), seta V longest, seta VI shortest; distoventral margin with two spinules (Fig. 6A).

A1 9-segmented (Fig. 7A), haplocer, prehensile, geniculation between segments 4-5 and 7-8 (as depicted for $R$. insolitus sp.n.) and with a peculiar hyaline tip on the distal segment; armature formula $0 / 5 / 4 / 2 / 5+\mathrm{Ae} / 1 / 3$ (one proximal spine, a large, anterior hyaline spine and a posterior seta) $/ 2$ (proximal hyaline spine and distal seta) $/ 7+$ acrothec (two setae + Ae).

A2 with allobasis (Fig. 7B), with 2 long setules proximally, and with two outer spinules inserted at the same level of the exp; with 1segmented exp with one seta, with thin spinules proximoventrally, two thick spinules distoventrally and seven setae/spines ornamented as figured.

Coxal gnathobase of Md (Fig. 7C) with tooth-like attenuations forming a sharp cutting edge and one seta, mandibular palp 1-segmented with two distal setae.

Praecoxal arthrite of Mx1 (Fig. 7D) with five elements (one dorsal surface seta, three 

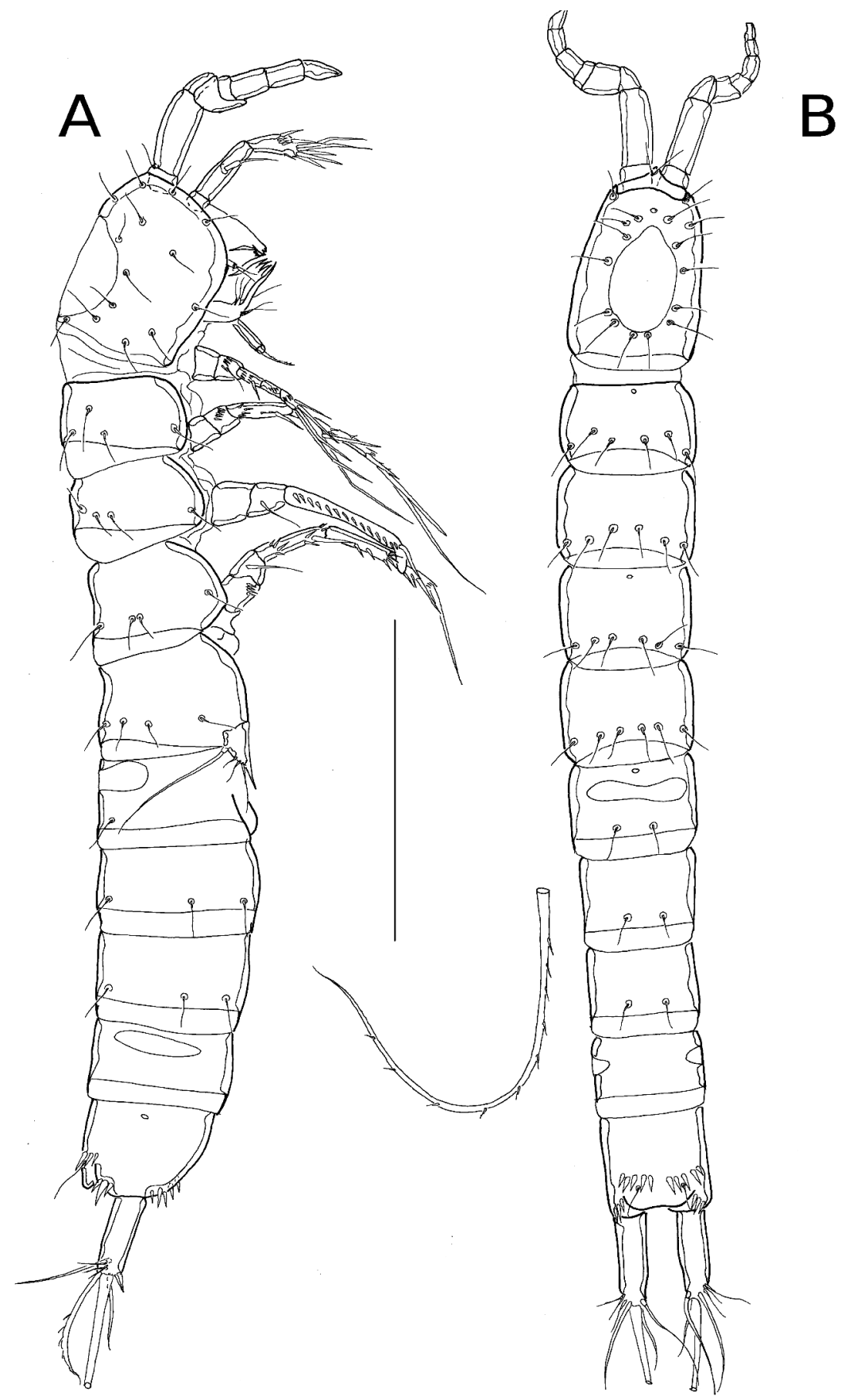

Fig. 6. Remaneicaris itacambirucui sp.n., male, holotype (INPA 1452 a-g). A - habitus, lateral; B - habitus, dorsal. Scale bar $100 \mu \mathrm{m}$.

Рис. 6. Remaneicaris itacambirucui sp.n., самец, голотип (INPA $1452 \mathrm{a}-\mathrm{g}$ ). A — габитус, латеральный вид; В — габитус, дорзальный вид. Масштаб 100 мкм. 


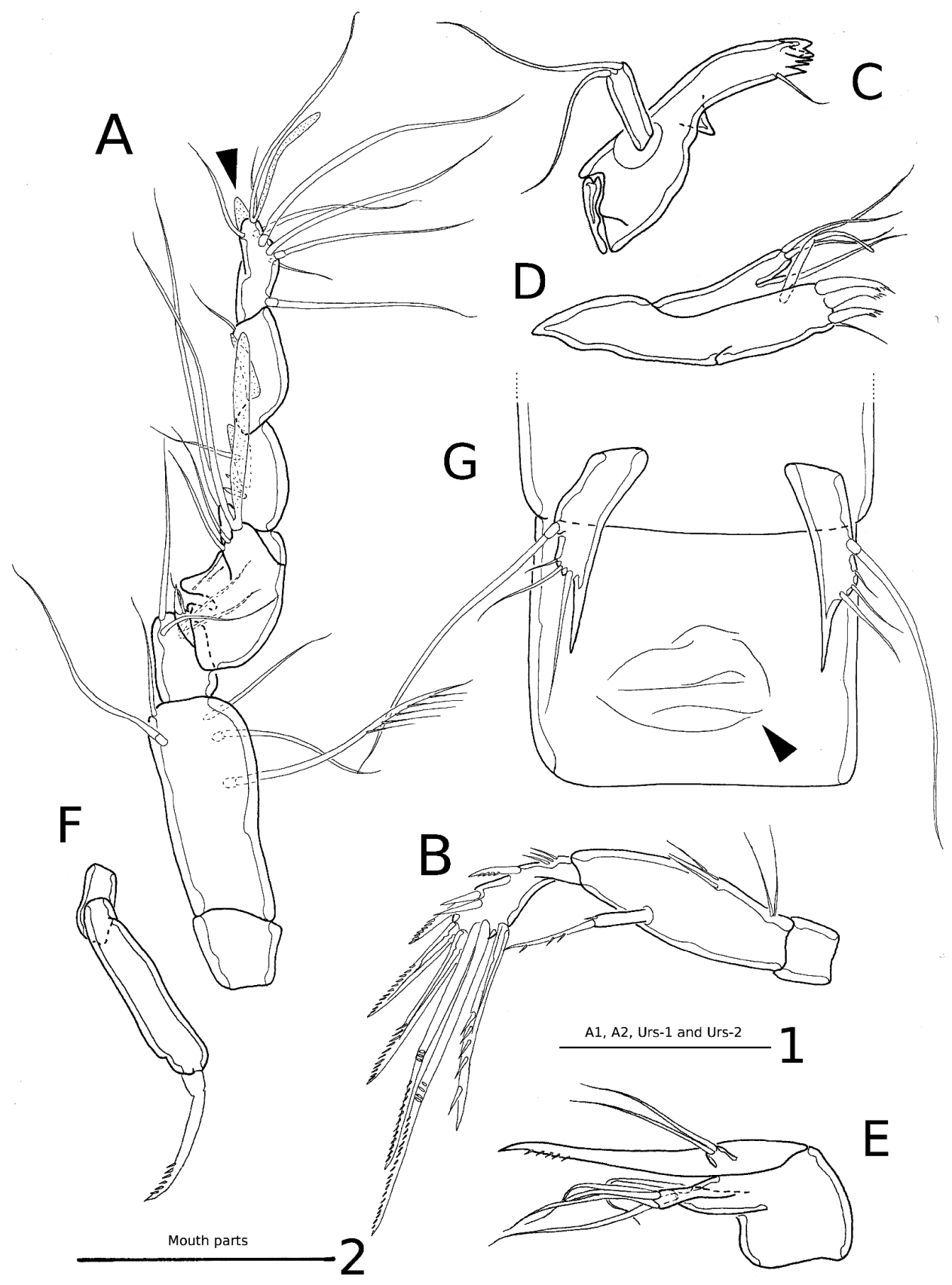

Fig. 7. Remaneicaris itacambirucui sp.n., male, holotype (INPA 1452 a-g).

$\mathrm{A}-\mathrm{A} 1$ (arrow head indicates the hyaline tip of the 9th segment); B $-\mathrm{A} 2 ; \mathrm{C}-\mathrm{Md}$; D $-\mathrm{Mx} 1 ; \mathrm{E}-\mathrm{Mx} 2 ; \mathrm{F}-\mathrm{Mxp}$; $\mathrm{G}$ - Urs-1 and Urs-2, ventral view, genital field arrowed. Scale bars $20 \mu \mathrm{m}(1-\mathrm{A} 1$, A2, Urs-1 and Urs-2; 2 - mouth parts).

Рис. 7. Remaneicaris itacambirucui sp.n., самец, голотип (INPA $1452 \mathrm{a}-\mathrm{g}$ ).

A - антеннула (стрелкой отмечена гиалиновая вершина девятого членик); В - антенна; C - мандибула; D максиллула; E - максилла; F - максиллипед; G - уросомиты 1 и 2, вид с брюшной стороны, генитальное поле отмечено стрелкой. Масштаб 20 мкм (1 - A1, A2, Urs-1 и Urs-2; 2 - ротовые части). 


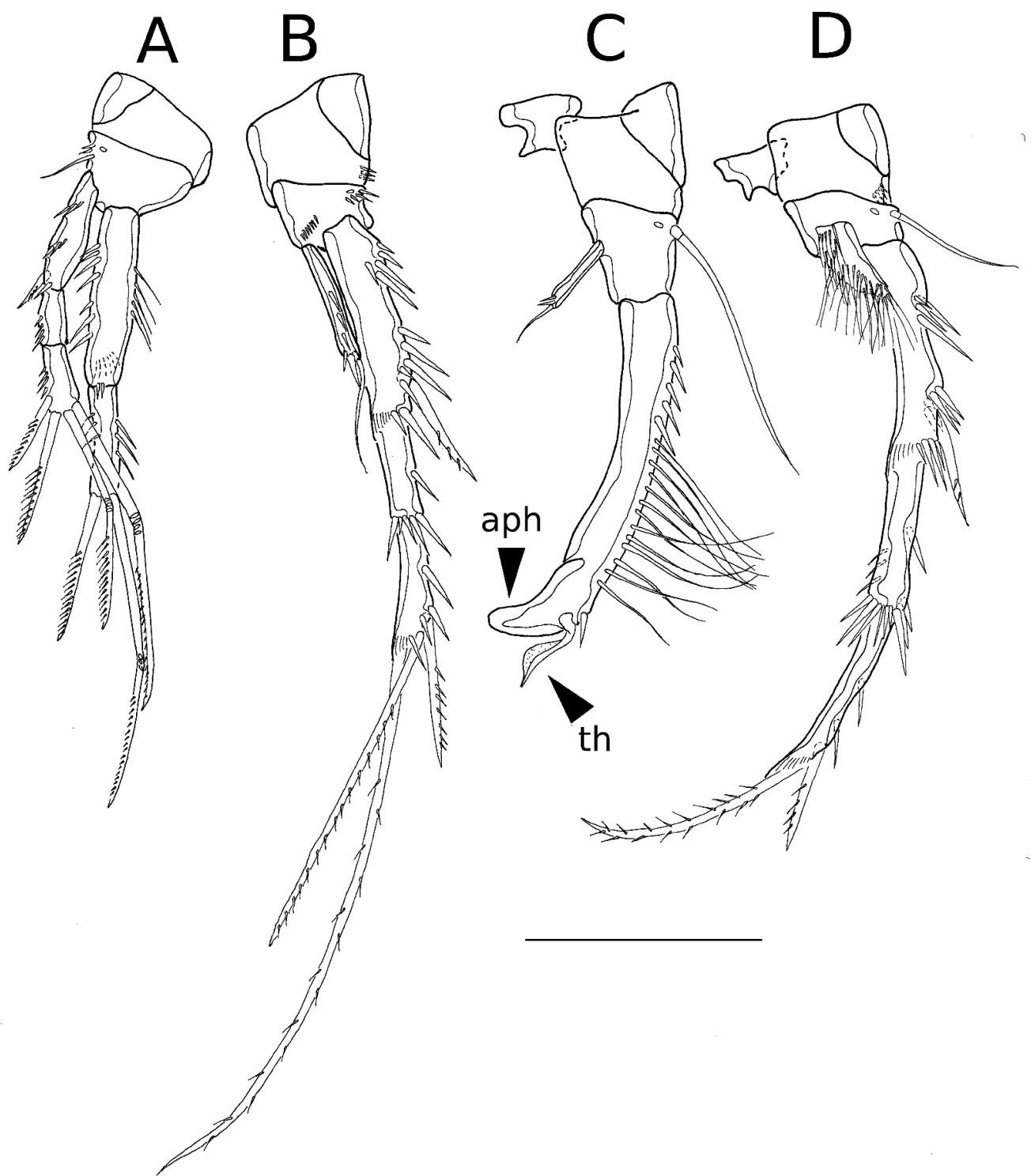

Fig. 8. Remaneicaris itacambirucui sp.n., male, holotype (INPA $1452 \mathrm{a}-\mathrm{g}$ ).

$\mathrm{A}-\mathrm{P} 1 ; \mathrm{B}-\mathrm{P} 2 ; \mathrm{C}-\mathrm{P} 3$ (arrow heads indicate the thumb (th) and the apophysis (aph)); D - P4. Scale bar $20 \mu \mathrm{m}$. Рис. 8. Remaneicaris itacambirucui sp.n., самец, голотип (INPA 1452 a-g).

A - плавательная нога 1; В - плавательная нога 2; C — плавательная нога 3 (стрелками отмечены пальцевидный выступ (th) и апофиз (aph)); D - плавательная нога 4. Масштаб 20 мкм.

claw-like pinnate spines and 1 slender seta), coxa with one seta, basis with three setae.

Basis of Mx2 (Fig. 7E) with two endites, proximal endite with two setae, distal endite with three slender setae, proximal endopodal segment drawn into a claw, distal endopodal segment with two setae.

Mxp (Fig. 7F) subchelate, composed of syncoxa, basis, 1-segmented enp and one claw-like apical seta. 
P1 (Fig. 8A) basis with outer seta, two outer spinules and one outer pore; exp 3-segmented, exopod segments ornamented as figured, exp-1 with outer spine, exp-2 unarmed, exp-3 with two outer spines and two geniculated setae; enp 2segmented, endopodal segments ornamented as shown, enp-1 with posterior hyaline frill; enp-2 with one distal spine, and a geniculate distal seta.

P2 (Fig. 8B) with unarmed coxa, with one posterior row of small spinules; basis without outer seta, with one outer row of spinules, an anterior pore and a row of spinules near the insertion of the enp; exp 3-segmented, exopodal segments ornamented as figured, exp-1 approximately of the same size as the remaining segments combined, with a proximal row of spinules distributed in a "V" shape on the outer margin, with 1 outer spine and a hyaline frill on the distal inner corner, exp-2 without armature, exp-3 with three spine/setae (one outer, short, unipinnate spine; one middle, long, bipinnate seta, and one inner, longer, bipinnate seta), and a distal hyaline frill on the distal inner corner; enp 1segmented with one distal seta, ornamented as figured.

P3 (Fig. 8C) with unarmed coxa; basis with long outer seta; enp 1-segmented, distally with one seta and two spinules; exp 1-segmented, elongated, ornamented with a row of outer spinules (distalmost spinules very long), thumb curved with a hyaline inner margin, apophysis curved inwards, longer than the thumb and with a rounded tip.

P4 (Fig. 8D) with unarmed coxa, the later, with a posterior row of spinules; basis with outer seta and one outer pore; exp 3-segmented, exopodal segments ornamented as depicted, exp1 shorter than the remaining segments combined, with a proximal row of spinules distributed in a "V" shape on the outer margin, with outer spine and a distal hyaline frill on the distal inner corner, exp-2 without armature, with a distal row of spinules on inner margin, exp-3 with two setae/spines (one subdistal unipinnate outer spine, and a distal bipinnate seta), with a distal hyaline frill on the inner corner; enp 1-segmented, short, leaf-shaped, ornamented as figured.
P5 without intercoxal plate, with a distal process on the inner margin, all setae inserted on the outer margin (Fig. 7G).

P6 unarmed, delicate genital aperture (Fig. $7 \mathrm{G})$.

Remaneicaris ivoneae sp.n.

Figs 9-11.

Holotype. One male dissected and mounted on 7 slides (INPA $1453 \mathrm{a}-\mathrm{g}$ ).

Etymology. The species is named after the senior author's aunt, Ivone Corgosinho Baumecker.

Type locality. Nhundiaquara River, State of

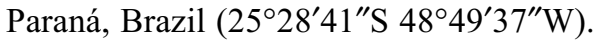

Male. Habitus, see Fig. 9A. Length $280 \mu \mathrm{m}$ (measured from the tip of the rostrum to the distal rim of the telson). Rostrum not fused to Cph (Fig. 9A), with a wide base and two sensilla on the tip. Cph with one dorsal integumental window (Fig. 9A). Dorsal pore on Ps2 and Ps4. Urs-2 with one dorsal integumental window and dorsal pore; Urs-5 with one integumental window on each side (Fig. 9B). Telson smooth dorsally (Fig. 9B, 10B), with lateral pore and ventrally with a row of four small spinules on each side of the somite close to the insertion of the furca (Fig. 9A-B, 10A); anal operculum smooth and convex (Fig. 9B, 10B).

Furca with seven setae; all setae located on the distal third; setae I, II and III inserted at the same level of seta VII; seta V longest, seta VI shortest, distoventral margin with two spinules (Fig. 10A-B); dorsally, with two spinules on the distal third of the furca (Fig. 10A-B).

A1 9-segmented (Fig. 11A), haplocer, prehensile, geniculation between segments 4-5 and 7-8 (as depicted for $R$. insolitus sp.n.) and with a peculiar hyaline tip on the distal segment; armature formula $0 / 5 / 4 / 2 / 5+\mathrm{Ae} / 1 / 3$ (one proximal spine, a large, anterior hyaline spine and a posterior seta) $/ 2$ (proximal hyaline spine and distal seta) $/ 7+$ acrothec (two setae $+\mathrm{Ae}$ fused).

A2 (Fig. 11B) with allobasis; 1-segmented exp with one seta, and 1-segmented enp bearing seven setae/spines as figured. 


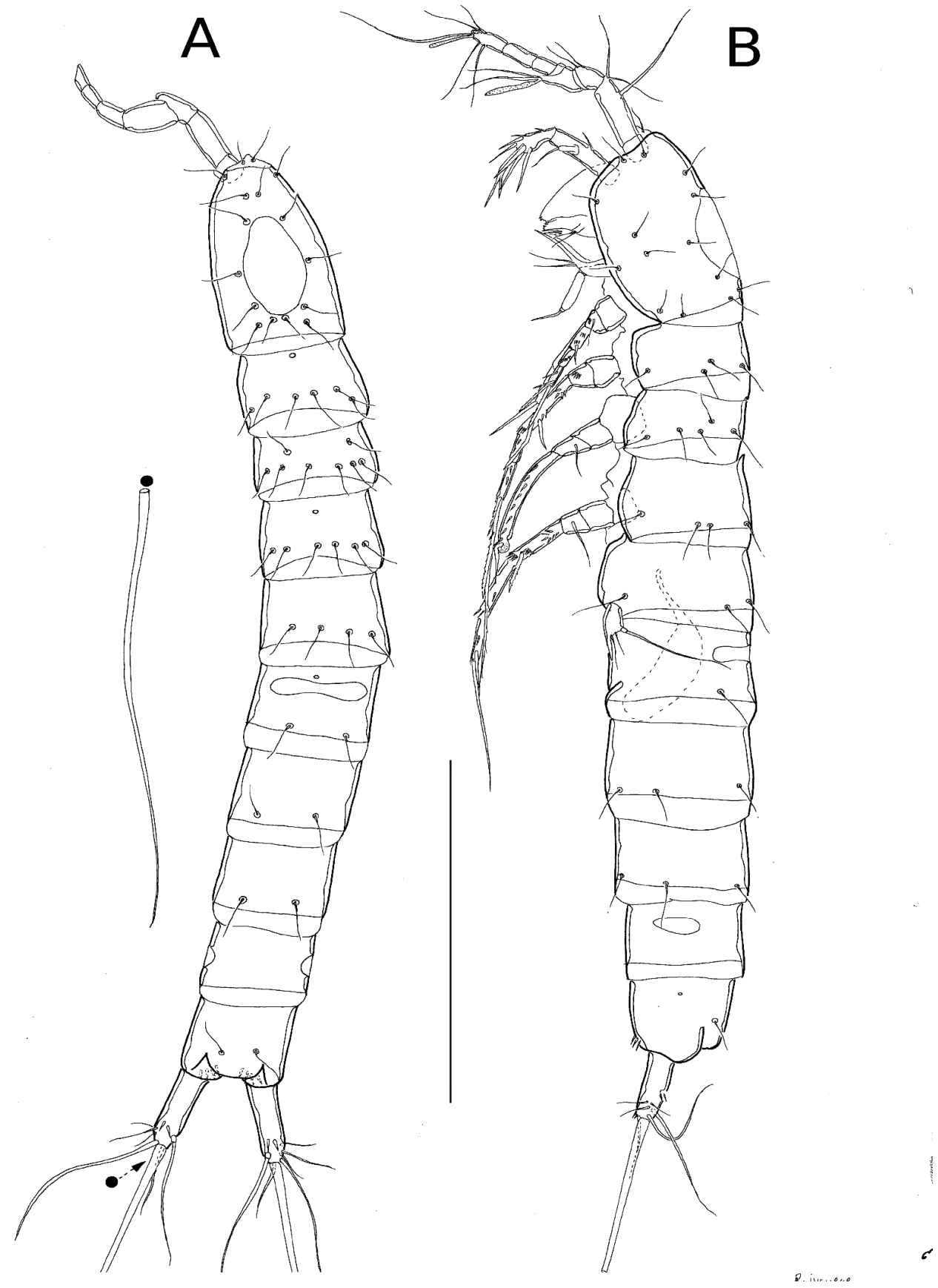

Fig. 9. Remaneicaris ivoneae sp.n., male, holotype (INPA 1453 a-g).

A - habitus, dorsal; B — habitus, lateral. Scale bar $100 \mu \mathrm{m}$

Рис. 9. Remaneicaris ivoneae sp.n., самец, голотип (INPA $1453 \mathrm{a}-\mathrm{g}$ ).

A - габитус, вид со спинной стороны; В — габитус, вид сбоку. Масштаб 100 мкм. 


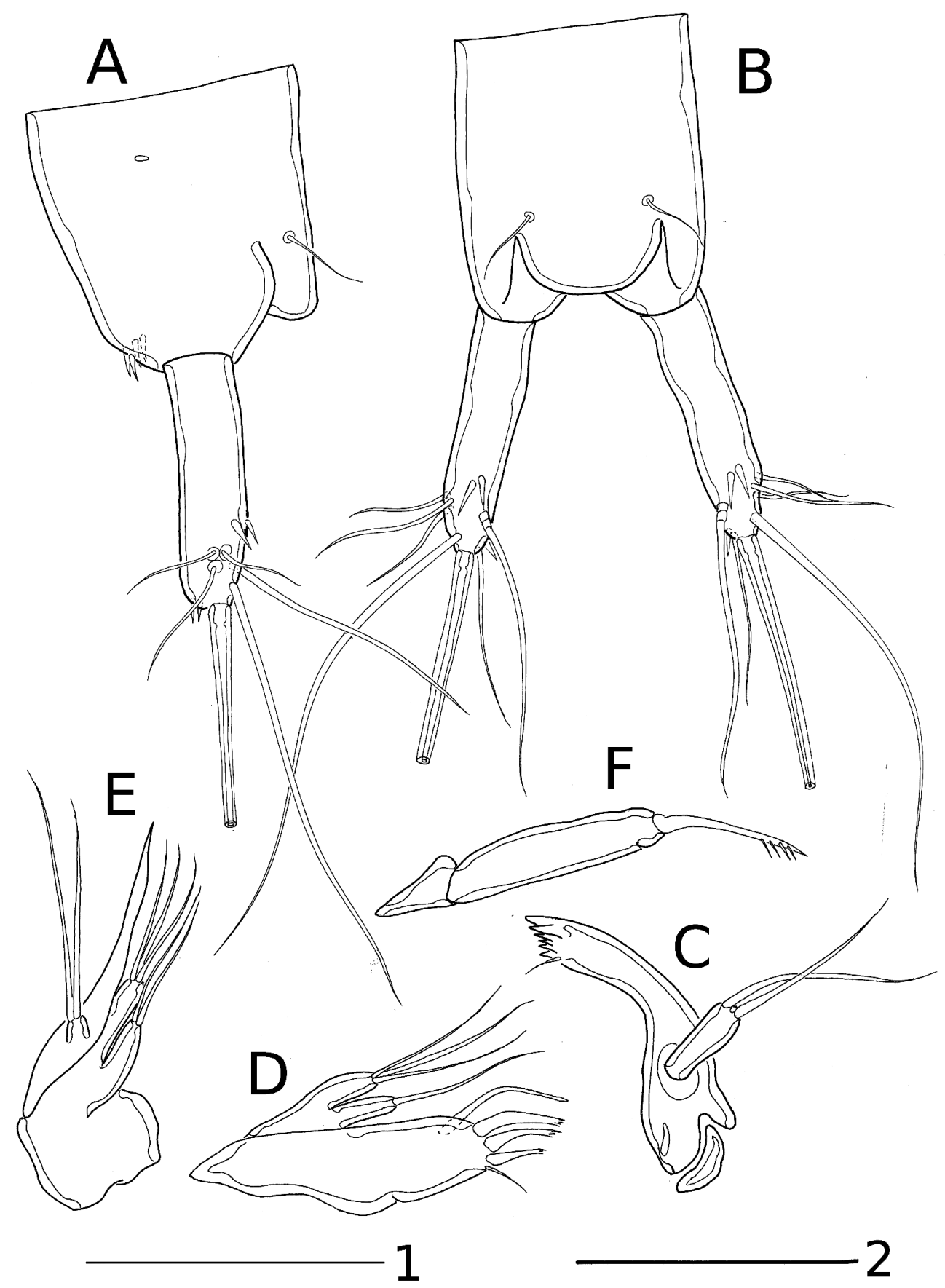

Fig. 10. Remaneicaris ivoneae sp.n., male, holotype (INPA $1453 \mathrm{a}-\mathrm{g}$ ).

$\mathrm{A}, \mathrm{B}$ - telson in lateral (A) and dorsal view (B); C - Md; D - Mx1; E - Mx2; F - Mxp. Scale bars $25 \mu \mathrm{m}(1-$ telson, 2 - mouth parts).

Рис. 10. Remaneicaris ivoneae sp.n., самец, голотип (INPA $1453 \mathrm{a}-\mathrm{g}$ ).

А,В - тельсон, вид сбоку (А) и вид со спинной стороны (В); С — мандибула; D - максиллула; Е — максилла; F - максиллипед. Масштаб 25 мкм (1 - тельсон; 2 - ротовые части). 


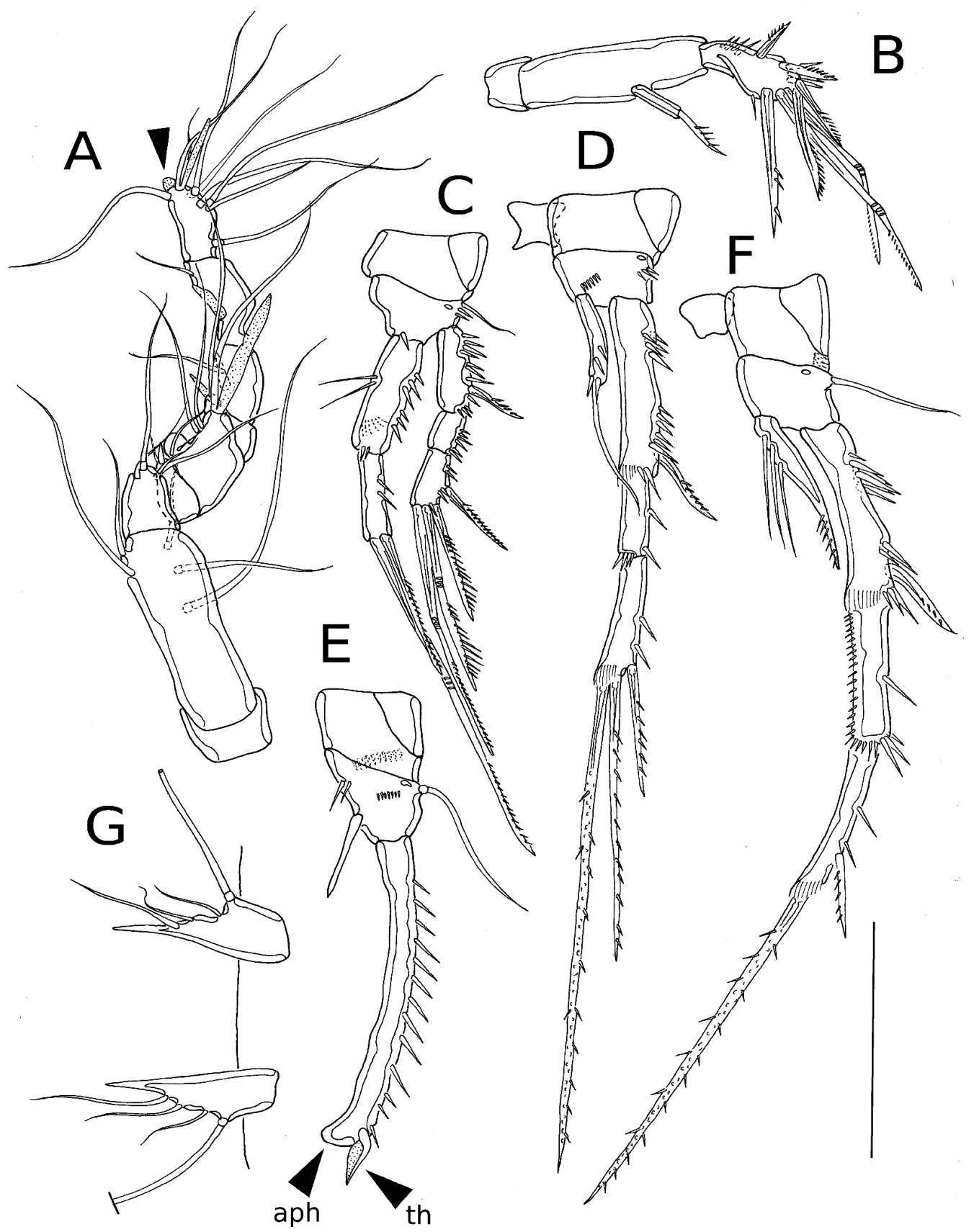

Fig. 11. Remaneicaris ivoneae sp.n., male, holotype (INPA $1453 \mathrm{a}-\mathrm{g}$ ).

$\mathrm{A}-\mathrm{A} 1$ (arrow head indicates the hyaline tip of the 9th segment); B - A2; C - P1; D - P2; E - P3 (arrow heads indicate the thumb (th) and the apophysis (aph)); F - P4; G - P5. Scale bar $20 \mu \mathrm{m}$.

Рис. 11. Remaneicaris ivoneae sp.n., самец, голотип (INPA $1453 \mathrm{a}-\mathrm{g}$ ).

A — антеннула (стрелкой отмечена гиалиновая вершина 9-го членика); В — антенна; C — плавательная нога 1; $\mathrm{D}$ - плавательная нога 2; $\mathrm{E}$ - плавательная нога 3 (стрелками отмечены пальцевидный выступ (th) и апофиз (aph)); F плавательная нога 4; G, нога 5. Масштаб 20 мкм. 
Coxal gnathobase of Md (Fig. 10C) toothlike attenuations formsharp cutting edge and one seta, mandibular palp 1-segmented with two distal setae.

Praecoxal arthrite of Mx1 (Fig. 10D) with five elements (one dorsal surface seta, three claw-like pinnate spines and one slender seta), coxa with one seta, basis with three setae.

Basis of Mx2 (Fig. 10E) with two endites, proximal endite with two setae, distal endite with three slender setae, proximal endopodal segment drawn into a claw, distal endopodal segment with two setae.

Mxp (Fig. 10F) subchelate, composed of syncoxa, basis, 1-segmented enp and one clawlike apical seta.

P1 (Fig. 11C) basis with outer seta and one pore on anterior outer margin, two spinules on the outer margin and one spinule near the insertion of the enp; exp 3-segmented, exp segments ornamented as depicted, exp-1 with outer spine, exp-2 unarmed, exp- 3 with two outer spines and two geniculated setae; enp 2-segmented, endopodal segments ornamented as figured, enp1 with posterior hyaline frill; enp-2 with one distal spine and a geniculated distal seta.

P2 (Fig. 11D) with unarmed coxa; basis without outer seta, ornamented with one row of outer spinules and a row of spinules near the insertion of the enp; exp 3-segmented, exopodal segments ornamented as figured, exp-1 of approximately the same size as the remaining segments, with a proximal row of spinules distributed in a "V" shape on the outer margin and with a hyaline frill on the distal inner corner, exp-2 without armature, exp-3 with three spines/ setae (one outer, short, unipinnate spine; one middle, long, unipinnate seta, and one inner, longer, bipinnate seta with some granules of uncertain nature), and a distal hyaline frill on the distal inner corner; enp 1-segmented, ornamented as figured, with one distal seta.

P3 (Fig. 11E) with unarmed coxa, with a posterior row of spinules; basis with outer seta, an outer pore, one row of spinules near the outer pore and two spinules on the inner margin; enp 1-segmented, club-shaped, without armature or ornamentation; exp 1-segmented, elongated, almost straight, ornamented with a series of spinules along the entire outer margin; thumb straight, with a hyaline inner margin; apophysis short and rounded.

P4 (Fig. 11F) with unarmed coxa, with a posterior row of spinules; basis with outer seta and one outer pore on the anterior margin; exp 3-segmented, exopodal segments ornamented as figured, exp-1 shorter than the remaining segments combined, with a proximal row of spinules distributed in a "V" shape on the outer margin and with a hyaline frill on the distal inner corner, exp-2 without armature, with a row of spinules along the entire inner margin and outer spinules, exp-3 with two setae/spines (one subdistal and unipinnate outer spine and a distal and bipinnate seta with inner granules of uncertain nature), with a distal hyaline frill on the inner corner; enp 1-segmented with three long inner spinules on the proximal third and a row of very small spinules covering the distal portion of the inner margin, enp without outer ornamentation.

P5 (Fig. 11G) without intercoxal plate, with a distal inner process, all setae inserted on the outer margin.

P6 unarmed, delicate genital aperture (similar to R. itacambirucui sp.n.).

\section{Discussion}

While taxonomic studies of large numbers of individuals of both genders are preferable, the practice of describing a new taxon based on a single specimen is in full compliance with the ICZN (1999; articles 72.5.1, 73.1.1 and 73.1.2). In addition, males of many species of copepods express secondary sex character states which are invaluable in separating species. The swimming leg 3 (4th thoracopod) is one such character for many podoplean copepods.

Remaneicaris itacambirucui sp.n., $R$. insolitus sp.n. and $R$. ivoneae sp.n. differ from each other in the number of integumental windows on the urosomite 2 and urosomite 5 (occurring, in $R$. insolitus sp.n., an additional division of the integumental window of the Urs- 2 into 2 dorsolateral windows), ventral ornamentation of the proximal region and distal margin of the telson 
(more ornamented in $R$. insolitus sp.n. and $R$. itacambirucui sp.n.), distal ornamentation of the flanking areas of the telson, not ornamented in $R$. ivoneae sp.n., dorsal ornamentation of the telson (with a preopercular row of spinules in $R$. itacambirucui sp.n.), shape of the swimming leg $3 \exp$ ("aberrant" in R. itacambirucui sp.n., with long setules inserted on the outer margin; never described before for any Parastenocarididae), endopod of the male swimming leg 4 (less ornamented in $R$. ivoneae sp.n.) and structure of the thumb (with a hyaline margin in R. itacambirucui sp.n. and $R$. ivoneae sp.n.).

Remaneicaris itacambirucui sp.n. seems to be closely related to $R$. ivoneae sp.n., with which it shares the presence of a hyaline inner margin on the thumb. However, the presence of a hyaline structure on the thumb is present also outside the "group-C". This is one of the most homoplasic characters within the genus, appearing four times in three different monophyletic groups (Corgosinho, 2007). For example, Corgosinho (2007) demonstrated that a thumb with hyaline margin appears in less inclusive groups within the "group-D" (Table 1) in species related to $R$. tridactyla ( $R$. paraguayensis and $R$. paraensis), in $R$. cordobaensis and in $R$. hecate. Thus, in the absence of more elucidative characters, the exact phylogenetic position of both species within the monophyletic group composite by $R$. analuizae, $R$. euniceae, $R$. tageae, $R$. divae, $R$. itacambirucui sp.n., $R$. insolitus sp. $\mathrm{n}$ and $R$. ivoneae sp.n. is difficult to determine.

In order to justify our decision to include Remaneicaris itacambirucui sp.n., R. insolitus sp.n. and $R$. ivoneae sp.n. within a group of species closelly related to $R$. analuizae, herewith we will discuss some key character that we consider as putative autapomorphies at different levels of generalization within the genus.

\section{Character discussion}

Distal margin of the 9th antennule segment of the male (character 7)

The species described here belong to the "group-C" of species (Fig. 12; Table 1) and are characterized by the presence of a hyaline mar- gin on the distal rim of the 9th segment of the male antennule (Fig. 12, character 7). Within Remaneicaris, this character was not observed outside the monophyletic group formed by the species closely related to $R$. analuizae (Table 1 , "group-C"). Among other parastenocaridid genera, it appears convergently in Kinnecaris giselae Schminke, 2008.

Apophysis of the swimming leg 3 (character 3) and modified spinule justaposed to the thumb (character 2)

The most important autapomorphies of the "group-A" are the presence of an apophysis with a hyaline margin (character 3 ) and the presence of a modified spinule on the distal margin of the exopodite 1 of male swimming $\operatorname{leg} 3$, juxtaposed to the thumb insertion (character 2).

Within Remaneicaris only $R$. divae and $R$. paraguayensis have a hyaline apophysis on the swimming leg 3 . However, these species belong to different monophyletic groups, namely "group-C" and "group-D" respectivelly (Table 1). A closer observation of these characters revealed that in $R$. divae, the apophysis is a hyaline bud at the distal rim of a straight swimming leg 3 and the thumb is a very long and straight spine, without the adjacent modified spinule. In $R$. paraguayensis the hyaline margin surrounds the whole rounded apophysis and a modified spinule at the distal rim of the exopodite 1 of the swimming leg 3 is also absent. In the "group-A", on the contrary, the apophysis has a very characteristic shape, with a welldeveloped hyaline margin, inwardly projected (commonly with a "pointed" edge; Fig. 12, character 3), at the end of a straight exopod, conferring to it a final angle of approximately $90^{\circ}$ with the main exopod axis.

The species belonging to the "group-B", including the new species described here, do not have a hyaline apophysis in the groundpattern. Thus, the presence of this character within Remaneicaris, outside the "group-A", should be seen as a homoplasy. Within the Parastenocarididae, other species and groups also have an apophysis with a hyaline margin. We can men- 
Table 1. List of species belonging to different monophyletic groups within the genus Remaneicaris. Letters from A to G identify each respective monophyletic entity within Remaneicaris and the correspondent species belonging to them. Remaneicaris icoaraci (Noodt, 1963) and R. psammae (Rouch, 1962) are not included in the table, since their exact phylogenetic position within the genus is still unclear. Inclusion of $R$. ahaggarica within the "group-A" is pending a redescription and designation of a neotype for this species. PMG - putative monophyletic groups.

Таблица 1. Списки видов монофилетических групп рода Remaneicaris. A-G - монофилетические группы рода Remaneicaris и соответствующие этим группам виды. Remaneicaris icoaraci (Noodt,

1963) и R. psammae (Rouch, 1962) не включены в таблицу из-за неясного филогенетического положения. Включение R. ahaggarica в “группу А” отложено до его переописания и выделения неотипа. PMG — предполагаемые монофилетические группы.

\begin{tabular}{|c|c|c|}
\hline \multicolumn{2}{|c|}{ PMG } & Species/ Виды \\
\hline 1 & & R. ignotus \\
\hline 2 & & R. meyerabichi \\
\hline A & & R. palaciosi; $R$. clandestina; $R$. drepanephora; $R$. argentina; $R$. hurdi; $R$. jujuyensis \\
\hline \multirow[b]{2}{*}{ B } & $\mathrm{C}$ & $\begin{array}{l}\text { R. analuizae; } R . \text { euniceae; } R . \text { divae; } R \text {. tageae; R. itacambirucui sp.n.; R. ivoneae } \\
\text { sp.n.; R. insolitus sp.n. }\end{array}$ \\
\hline & $\mathrm{D}$ & 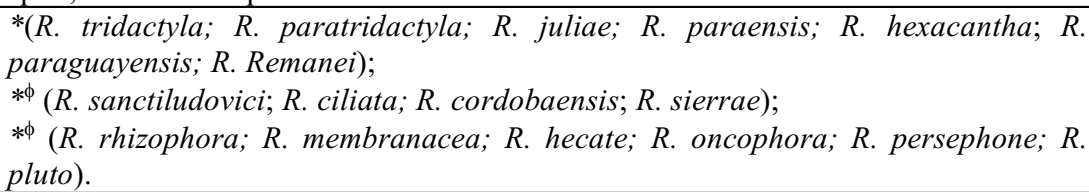 \\
\hline
\end{tabular}

*(species) - identify the different monophyletic groups within "group-D”, in accordance with Corgosinho (2007) $\Phi$ - identify a large monophyletic group composite by the species closely related to $P$. cordobaensis and $R$. persephone.

*(виды) - обозначение монофилетических групп в “группе D" (Corgosinho, 2007). Ф - обозначение крупной монофилетической группы, включающей виды близкие к P. cordobaensis и R. persephone.

tion $P$. arenosus Fryer, 1956, $P$. monodi Chappuis, 1959, P. marlieri Chappuis, 1955, P.crassicaudis Chappuis, 1955, P. tapajoensis Noodt, 1963, most of Forficatocaris Jakobi, 1972 species, Brasilibathynellocaris Jakobi, 1972 species and some Potamocaris Dussart, 1970. However, these species belong to different evolutionary lines within the Parastenocarididae and the presence of this structure is not homologous among these taxa.

Inner row of spinules on the inner margin of endopodite 1 of the swimming leg 1 (character 4)

Lang (1948) had already mentioned the importance of this structure within Parastenocaridiae, although referring to it as an "innere Borste" (inner seta). However, no Parastenocarididae has an inner seta on the endopodite 1 of the swimming leg 1. Martínez Arbizu and Moura (1994) consider the loss of this seta as one of the most important synapomorphies of a taxon formed by Psammonitocrella Huys, 2009 + Parastenocarididae. Nevertheless, it is conceivable that this character is lost inependently within Parastenocarididae and Ameiridae.

The presence of an inner ornamentation on the endopodpodite 1 of the swimming leg 1 is widespread in different evolutionary lineages within Harpacticoida and has been used to define monophyletic groups within Parastenocarididae (e.g. Ahnert, 1994 used the presence of inner modified spinules on the endopod 1 of the swimming leg 1 to define the monophylum Potamocaris/Forficatocaris).

As a shared plesiomorphic character, all species from "group-B" have the inner margin of the endopodite 1 of the swimming leg 1 ornamented with long setules. Within Remaneicaris a row of spinules on the inner margin of endopodite 1 of the swimming leg 1 is absent only in the "group-A" and constitute what we 


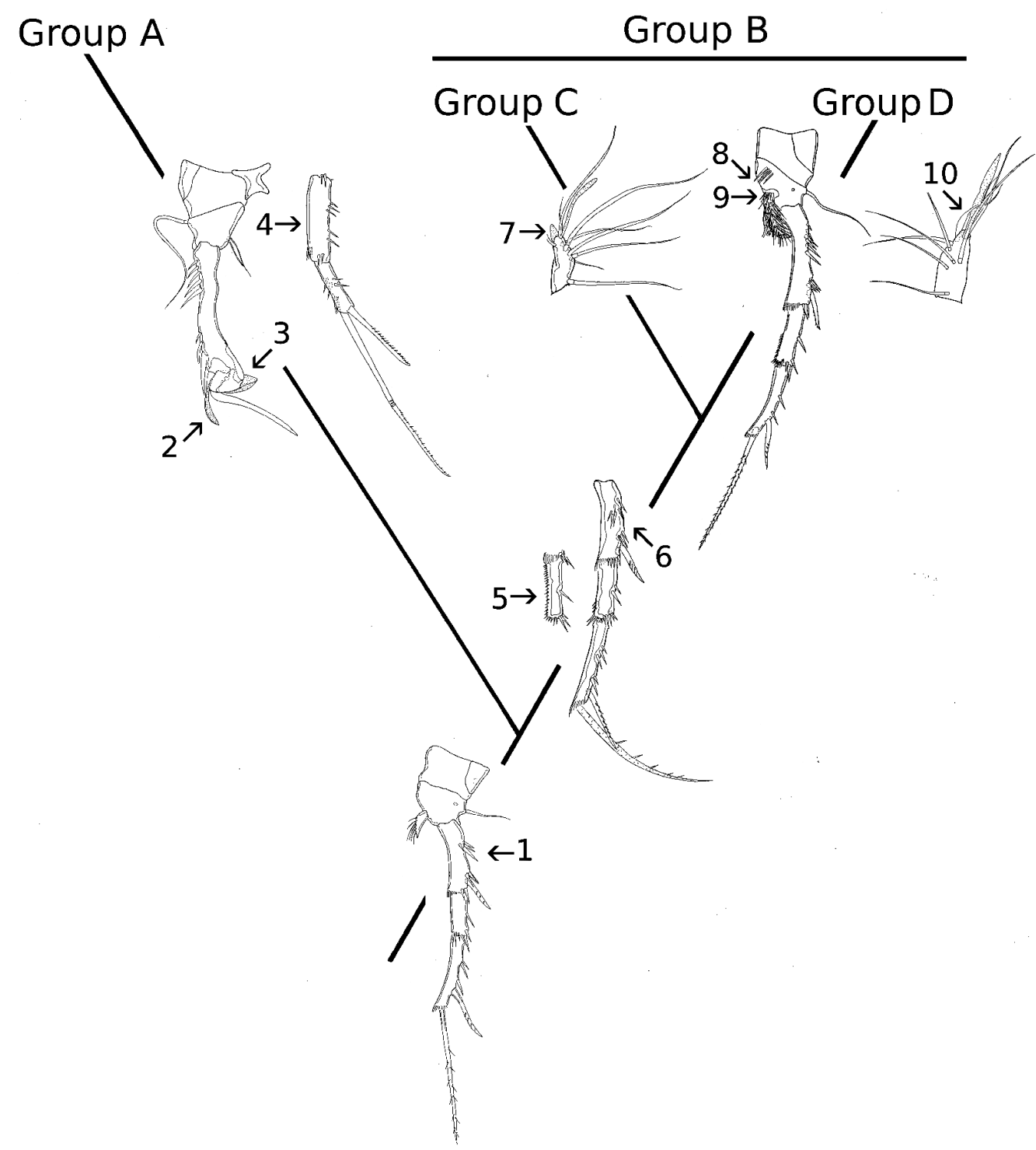

Fig. 12. Pictorial cladogram illustrating the hypothesized phylogenetic relationship between monophyletic groups within the genus Remaneicaris. Chosen pictures represent some key characters considered as autapomorphic at different levels of generality, but not all the characters chosen to depict the phylogeny of the group. Numbers followed by arrows indicate the character where it appears as autapomorphic. Further explanation is given in the text. For species within groups see Table 1. Complete data available on Corgosinho's (2007).

Fig. 12. Кладограмма филогенетических отношений монофилетических групп рода Remaneicaris. Изображения иллюстрируют некоторые ключевые признаки, рассматриваемые как аутапоморфии. Номерами и стрелками отмечено положение аутапоморфных признаков. Объяснение в тексте. Виды и их группы приведены в Таблице 1. Более подробные сведения о признаках представлены в работе Коргосинхо (Corgosinho, 2007). 


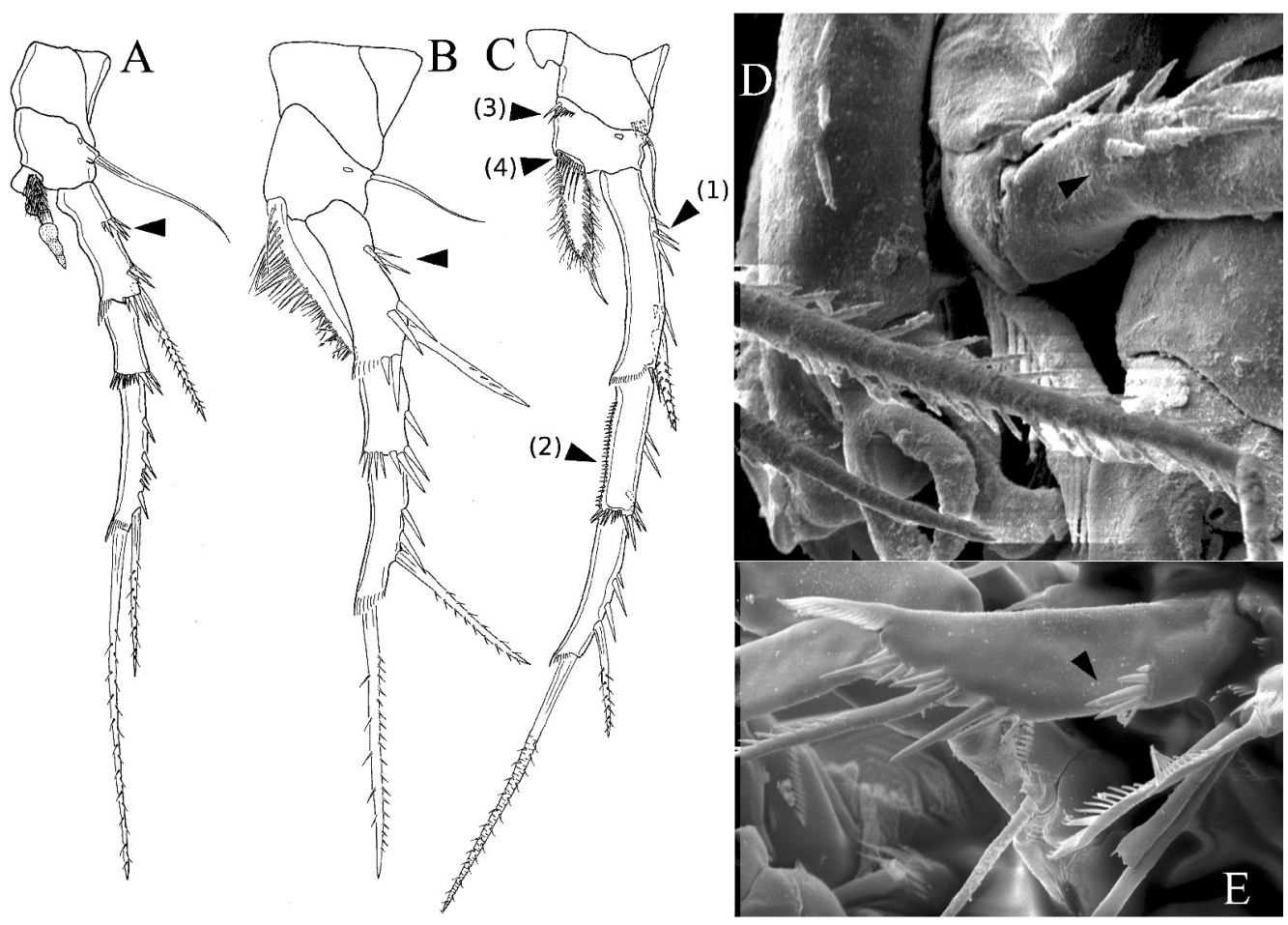

Fig. 13. Hypothetical series of transformation (from A to C) for the proximal outer row of spinules of P4 exp-1.

A - arrangement in line of the proximal outer row of spinules observed in Remaneicaris ignotus; B - proximal outer row of spinules develop into a soft "V"-shaped row of spinules as seen, in the following example, in $R$. argentina (also in all species composing the "group-A"); $\mathrm{C}$ - further development of this ornamentation into a strong "V"-shaped row of spinules as illustrated here for $R$. tridactyla (also present in all species composing "group-B"); D — partial SEM view of $R$. paratridactyla thoracopods showing, in the upper right corner of the picture the strong "V"-shaped row of spinules of P4 exp-1. E - partial SEM view of Potamocaris bidens thoracopods showing a horizontally oriented P2 with a linear row of spinules on the proximal region of the outer margin of P2 (it is serially homologous to the same structure on P4). Arrows and numbers are explained in the text.

Рис. 13. Гипотетический морфологический ряд (от А к С) изменения ряда шипиков, расположенного проксимально на внешнем крае первого членика экзоподита 4-й плавательной ноги (Р4 ехр-1).

A - расположение шипиков в линию, отмеченное у Remaneicaris ignotus; В — слабо выраженное «V»-образное расположение ряда шипиков, как показано на примере R. argentina и характерно всем видам «группы А»; С хорошо выраженное «V»-образное расположение ряда шипиков, как показано на примере R. tridactyla и отмечено у всех видов «группы В»); D - CЭМ фото торакопод R. paratridactyla, показывающее хорошо выраженное «V»-образное положения ряда шипиков на первом членике экзоподита 4-й плавательной ноги. ЕСЭМ фото торакопод Potamocaris bidens, показывающее горизонтально ориентированную плавательную ногу 2 с линейным расположением шипиков (серийно-гомологичных шипикам плавательной ноги 4). Обозначение стрелок и номеров дано в тексте.

consider a very distinctive autapomorphy for this monophylum.

Most of the Remaneicaris species described to date (23 species; Table 1 and Fig 12 "groupB") share the synapomorphies number 5 and 6 depicted in the Figs 12 and $13 \mathrm{C}$ (character 1 and 2) and 13D. Within this large monophyletic group two clear evolutionary linneages are evident. These groups can be easily identified on the basis of the structure (Fig. 12, character 7) and armatue (Fig. 12, character 10) of the last segment of the male antennule and the ornamentation of the basis of the male swimming leg 4 (Fig. 12, characters 8 and 9) (Corgosinho, 2007). 
Inner row of spinules on the exopodite 2 of the swimming leg 4 (character 5)

Remaneicaris insolitus sp.n., R. itacambirucui sp.n. and $R$. ivoneae sp.n. belong to a larger group ("group-B", Table 1 and Fig. 12) that has, as an autapomorphy, an inner row of spinules on the exopodite 2 of the swimming leg 4 (Fig. 12, character 5; Fig. 13C-(2))

An inner row of spinules on the exopodite 2 of the swimming leg 4 is absent in the more basal species within Remaneicaris such as $R$. ignotus (Dussart, 1983) (Fig. 13A), R. meyerabichi (Noodt, 1962) and the species closely related to $R$. argentina (Fig. 12 and table 1, "group-A").

The same structure appears in other species outside Remaneicaris, but in these cases, it seems restricted to some species closely related to Fontinalicarisfontinalis (Chappuis, Schnitter, 1915).

Proximal ornamentation of the outer margin of the exopodite 1 of the swimming legs 2 and 4 (character 6)

A proximal row of pronounced $\mathrm{V}$-shaped spinules (Fig. 12, character 6; Fig. 13C, character 1 and 13D) on the outer margin of the exopodite 1 of the swimming leg 2 and 4 appears only in a more derived group of species within Remaneicaris (Fig. 12 and Table 1, "group-B"). Within this genus, a clear series of transformation involving this ornamentation can be hypothesized. The plesiomorphic condition, observed in R. ignotus, is represented by a proximal row of linearly distributed spinules on the outer margin of the exopodite 1 of the swimming leg 4 (Fig. 13A). The same condition can be seen, for example, on the swimming leg 2 of Potamocaris bidens (Noodt, 1955) (Fig. 13E). It appears as a weakly pronounced V-shaped row of spinules in the groundpattern of a clade formed by (R. meyerabichi ("group-A", "group$\mathrm{B}$ ”)), being retained as a symplesiomorphy for the species composing "group-A". (Fig. 12, character 1; Fig. 13B; Table 1, "group-A"). Finally, it develops into a pronounced $\mathrm{V}$-shaped row of spinules within the "group-B".

Here, it is worth emphasizing that the transformation undergone by the proximal row of outer spinules of the exopodite 1 of the swim- ming leg 2 and 4 seems to occur concomitantly. In other words, there is no evidence that the plesiomorphic linear arrangement of spines was conserved in one of these legs but transformed in the other.

Proximal ornamentation of the basis of the swimming leg 4 (character 8)

The most speciose group (Table 1, Fig. 12, "group-D") is characterized by the presence, in males, of a row of spinules on the inner margin of the basis of the swimming leg 4 (Fig. 12, character 8; Fig. 13C-(3)).

Normally, the fine ornamentation was omitted in old descriptions, making difficult to say if this structure is present in other groups within the family. For example, a closer observation of an apparently homologous structure present in Brasilibathynellocaris spp. revealed a strong difference in form and position. Hence, the two strong "spines" present proximally on the inner margin of the "basis" of the male swimming leg 4 of Brasilibathynellocaris spp. (viz diagnose for the Parastenocaris panamericana-group in Noodt, 1962: 246) are, in fact, two well-developped spinules inserted on the coxa (Corgosinho et al., 2010).

However, even considering a widespread occurrence of a similar ornamentation within the family, clearly the presence of such character is a unique autapomorphy for a more derived monophylum within Remaneicaris ("group-D”) and certainly do not compose the groundpattern of the genus.

Chitinization of the basis of the swimming leg 4 and associated ornamentation (character 9)

The presence of a poorly chitinized region on the basis of the male swimming leg 4, near the insertion of the endopod is an interesting character of $R$. insolitus sp.n. With the exception of this species, this structure has been observed only in the groundpattern of a more inclusive monophylum formed by species closelly related to $R$. tridactyla, $R$. persephone and $R$. cordobaensis (Corgosinho, 2007; table 1, "groupD”, Fig. 12, character 9 and Fig. 13C-(4)). In the 
species constituting the "group-D" (with the exception of those species closelly related to $R$. cordobaensis), a well developed row of spinules, close to the insertion of the endopod, inserts on a poorly chitinized area (Figs 12, 13C). Other species within Parastenocarididae also have a row of spinules near the insertion of the endopod, such as the $P$. brevipes-group and P. minuta-group. A row of spinules can be seen also in the $P$. nana-group. However, a poorly chitinized region has not been found in any of these groups mentioned above, or have not been figured.

With the data available to date, it is more parsimonious to asume that the character 9 is an autapomorphy in the groudpattern of the "groupD". It appears convergently in $R$. insolitus sp.n, not appearing outside the genus Remaneicaris. A row of spinules inserting in a poorly chitinized area near the insertion of the endopod is absent in R. insolitus sp.n.

Armature of the 9th segment of the male antennule (character 10)

The presence of a modified seta on the last segment of the male antennule is one of the most important synapomorphies of the "group-D" (Corgosinho, 2007; Fig. 12, character 10). It appears as a proximal dilatation of the innermost seta of the male antennule. In the other species within the genus, this seta shows a normal shape and in the "group-C" it appears as an inner seta, separated from the others by the distal hyaline margin. The presence of this modified seta has never been described for other species of Parastenocarididae and probably evolved within the family only once.

\section{Convergent characters within Parastenocarididae}

\section{Integumental windows}

Within Parastenocarididae, number, presence and shape of the integumental windows have been a mater of controversy (i.e. Reid 1994; Corgosinho and Martínez Arbizu, 2005; Corgosinho et al., 2007). Most of the original descriptions lack the illustration of these structures, thus making difficult the interpretation of the evolution of this character without the observation of the types. In Remaneicaris, the presence, position and number of these structures have been important for the reconstruction of the phylogeny of the group (Corgosinho, 2007). In accordance with Corgosinho and Martínez Arbizu (2005), a complex series of transformation may have been involved, with a gradual modification of the position, shape and presence of this structure in different urosomites. However, with the data available to date, the most parsimonious hypothesis does not give support to the scenario proposed before by Corgosinho and Martínez Arbizu (2005). Therefore, it is more parsimonious a hypothesis involving (considering only the males) the loss of the dorsal integumental window of the urosomite 3 and 4, the splitting and lateral migration of the integumental window of the urosomite 5 and then, the split, into two dorsolateral windows, of the dorsal integumental window present on the urosomite 2.

Other evolutionary scenarios, although conceivable, are less parsimonious. Therefore, on the absence of contradictory evidences, other patterns within the genus, such as the presence of a lateral integumental window on the male urosomite 4, as observed in $R$. analuizae, is considered here as an independent evolution (Corgosinho et al., 2007).

The last transformation of the integumental window of the urosomite 2 of a monophyletic group related to $R$. persephone could make difficult the reconstruction of the phylogeny of Remaneicaris. Noodt (1965) did not illustrate or mention the splitting of the dorsal integumental window of the urosomite 2 into two parts. However, this is a synapomorphy for a group consisted of $R$. oncophora, $R$. pluto, $R$. hecate, $R$. persephone, $R$. rhizophora and $R$. membranacea. A similar structure appears also in $R$. insolitus sp.n. However, it is clearly homoplasic, since $R$. insolitus does not share with the species closely related to $R$. persephone the ornamentations present on the basis of the male swimming leg4 (Fig. 12, character 8 and 9; Fig. 13C-(3,4)) and the transforma- 
tion of the antennule seta (Fig. 12, character 10). Moreover, $R$. insolitus sp.n. has a hyaline margin on the 9th (last) antennule segment of the male, a character that we hypothesize as autapomorphic for the "group-C", not appearing in any other group within Remaneicaris. Remaneicaris insolitus sp.n. can be easily identified and distinguished by the presence of a double integumental window on each side of the urosomite 5 . This is a very peculiar character not seen before within the family.

Recently, Karanovic (2004, 2005), Ranga Reddy and Schminke (2009) and Schminke (2008) demonstrated the presence of lateral integumental windows on urosomite 4 and urosomite 5 of species in the genus Kinnecaris Jakobi, 1972. A similar pattern is observed in Monodicaris Schminke, 2009, whereas in M. larsi Schminke, 2009, two additional dorsolateral integumental windows were described for urosomite 2 and urosomite 3. A superficial analysis of this character and other structures such as the ornamentation along the outer margin of the exopodite 2 and 3 of the swimming legs 2-4, could be considered as an evidence of a close relationship between the genus Kinnecaris and Remaneicaris.

However, lateral integumental windows are not present in the groundpattern of Remaneicaris (Corgosinho, 2007; Corgosinho et al., $2007 \mathrm{a}-\mathrm{b}$ ) and the presence of lateral integumental windows on the male urosomite 4 is present only in $R$. analuizae. In view of the current evidences, any hypothesis toward the inclusion of Remaneicaris within Kinnecaris, or vice versa, or even as sister groups are not parsimonious.

\section{Telson ornamentation}

Ornamentation of the telson is also a very variable character within the genus Remaneicaris. It is more developed in the species around R. tridactyla (Table 1, "group *", within "groupD"), most notably in $R$. remanei, $R$. paratridactyla and $R$. juliae. In this group, it appears as a dorso-distal row of spinules located directly before to the preopercular sensilla, a proximal row of spinules also on the dorsal side of the telson and a well-developed row of spinules on the ventral side, close to the insertion of the furca. Other species from different monophyletic groups within Remaneicaris also display these characters, probably as a consequence of convergent evolution (Corgosinho, 2007). For example, in the monophyletic group of species closely related to R. analuizae (Table 1, "groupC"), R. itacambirucui sp.n. has a dorso-distal row of spinules, whereas within "group-D" (see Table 1), $R$. ciliata (Noodt, 1965), R. sierrae (Noodt, 1965) and $R$. persephone also have a similar structure.

The presence of postopercular ornamentation is one of the autapomorphies for the group of species related to $R$. analuizae (Corgosinho, 2007; Table 1, "group-C"). Within this group, only $R$. ivoneae sp.n. does not have such structure, probably as a consequence of secondary loss. Within Remaneicaris, this character appears independently in $R$. paraensis (Corgosinho, 2007) and R. ciliata (Noodt, 1965) (Corgosinho, 2007). Furthermore, Parastenocaris mateusi Noodt, Galhano, 1969, P. spinicauda Wells, 1964 and $P$. bolbodes Kiefer, 1968, have such character. However, Parastenocaris mateusi and $P$. spinicauda clearly belong to a monophyletic group not directly related to $R e$ maneicaris, sharing the presence of an inner process on the penultimate segment of the male antennule as an autapomorphy for a large group within the family (for subfamilies within Parastenocarididae, see Schminke, 1993, 2010). Parastenocaris bolbodes belongs to another evolutionary branch within the family, closely related to Fontinalicaris fontinalis and closer related to $P$. mateusi and $P$. spinicauda than to Remaneicaris (Corgosinho, 2007).

The presence of a continuous row of spinules on the proximal region of the ventral side of the telson is considered a synapomorphy for $R$. insolitus sp.n. and $R$. divae. Remaneicaris tage$a e, R$. euniceae and $R$. analuizae also have some ornamentation on the proximal region of the ventral side of the telson. However, in these species, this ornamentation is not formed by a continuous row of spinules, but by one small row of spinules on each side of the telson. 
Rejecting a close relationship between Remaneicaris, Kinnecaris and the Parastenocaris bevipes-group

Kinnecaris and Remaneicaris belong to different evolutionary groups within Parastenocarididae. Kinnecaris belongs to a more derived group within the family whose members share a special type of geniculation mode of the male antennule where the penultimate segment is transformed, displaying a strong process on the inner distal margin. While grasping, the penultimate segment is moved against the previous one, and the distalmost segment is moved outwardly and has no function in grasping. (Schminke, 1993, 2010). According to Schminke $(1993,2010)$ this type of antennule is characteristic of a large group of species closely related to the Parastenocaris brevipes-group (sensu Reid, 1995 and Galassi, De Laurentiis, 2004). In Remaneicaris and other Parastenocarididae closely related to Fontinalicaris fontinalis (i.e. species belonging to the genera Murunducaris Reid, 1994, Brasilibathynellocaris, Siolicaris Jakobi, 1972, Potamocaris, Forficatocaris, etc) the penultimate segment of the male antennule bends against its proximal segment and the last segment of the antennule bends dorsally against the 5th segment.

Other data support a distant phylogenetic relationship between Remaneicaris and $P$. brevipes (and species closely related to this species). Remaneicaris probably is the most basal group within the family (Corgosinho, 2007; Corgosinho et al., 2007), differing from all other Parastenocarididae in some unique plesiomorphic characters within the family.

For example, in accordance with Corgosinho (2007), the presence of an endopod on the male swimming leg 3 is a plesiomorphy of the genus Remaneicaris; its absence is a synapomorphy of the remaining Parastenocarididae.

Finally, for species in parastenocardid genera other than Remaneicaris, the transformation of one of the setae of the distal endite of the maxillary basis into a serrulated spine is an additional distinctive character shared by all Parastenocarididae. Corgosinho et al. (2005, $2007 \mathrm{a}-\mathrm{b}$ ) also proposed that only Remaneicaris species would retain two setae on the proximal endite of the maxillary basis. However, at least K. goddavary Ranga Reddy et Schminke, 2009 was described with this feature. The observation of some other species, whose the proximal endite of the maxillary basis was described with two setae (viz. P. brevipes and Murunducaris juneae Reid, 1994), revealed the presence of only a single seta on this endite (Corgosinho, 2007; Corgosinho et al., 2007a-b; Corgosinho et al., 2008). Therefore, the presence of this character in Kinnecaris needs to be confirmed. Even if the presence of this character is confirmed for the groundpattern of Kinnecaris, it is a plesiomorphy and cannot be used to endorse any close relationship between Remaneicaris and Kinnecaris. Schminke (2009) seems to be right when he suggested a close relationship between Monodicaris and Kinnecaris.

\section{Acknowledgements}

We would like to thank the Deutscher Akademischer Austausch Dienst "DAAD" the Fundação de Amparo a Pesquisa do Estado do Amazonas (FAPEAM) and the Forschungsinstitut Senckenberg for the financial support of the senior author. We are indebted to the DZMB - Senckenberg Forschungsinstitut and the Instituto Nacional de Pesquisas da Amazonia for the logistic support during this work. Prof. Dr. Schminke (University of Oldenburg) for discussions on parastenocaridid phylogeny and Dr. Thomas Glatzel (University of Oldenburg) for allowing us to study his personal collection of Parastenocarididae. This study would not have been possible without the study of Noodt's type material under curatorship of Prof. Dr. Pedro Martínez Arbizu. We are especially indebted to Dr. Celio Ubirajara Magalhães for his outstanding curation of the invertebrate collection of the National Institute of Amazonian Researches (INPA - Brazil) and Dr. Ahmed Ahnert who curated Noodt's material in the past and put it at our disposal for the present study. Finally, the final and ameliorated version of this manuscript could not be possible without the valuable comments and ideas offered by the reviewers. 


\section{References}

Ahnert A. 1994. Eidonomie, Systematik und Entwicklung von Potamocaris Dussart, 1979 und Forficatocaris Jakobi, 1969 (Copepoda, Harpacticoida, Parastenocarididae) sowie Verteilung im Lebensraum und Verhalten zweier koexistierender Vertreter beider Gattungen an einem sandigen Flußabschnitt im Küstengebirge von São Paulo (Brasilien). PhD Thesis. Kiel: Christian-Albrechts-Universität. $226 \mathrm{~S}$.

Ax P. 1984. Das phylogenetische System (Systematisierung der lebenden Natur aufgrund ihrer Phylogenese). Stuttgart: Gustav Fischer Verlag. 349 S.

Chappuis P.A. 1942. Eine neue Methode zur Untersuchung der Grundwasserfauna // Acta Scientifica der Mathematisch-Naturwissenschaftlichen Universität Francisco Josephinae Koloszvar. Vol.6. P.1-17.

Corgosinho P.H.C. 2007. Phylogenetic systematic of Remaneicaris Jakobi (Copepoda, Harpacticoida, Parastenocarididae) from the Neotropical region. $\mathrm{PhD}$ Thesis. Manaus: Instituto Nacional de Pesquisas da Amazonia, Universidade Federal do Estado do Amazonas. 326 p.

Corgosinho P.H.C, Martínez Arbizu P. 2005. Two new interstitial species of Remaneicaris Jakobi (Copepoda, Harpacticoida, Parastenocarididae) from the Ribeirao do Ouro river, Brazil, with a redefinition of the genus // Senckenbergiana Biologica. Bd.85. S.147-162.

Corgosinho P.H.C., Martínez Arbizu P., Santos-Silva E.N. 2007a. Three new species of Remaneicaris Jakobi, 1972 (Copepoda, Harpacticoida, Parastenocarididae) from the Ribeirao do Ouro River, Minas Gerais, Brazil, with some remarks on the groundpattern Parastenocarididae // Zootaxa. Vol.1437. P.1-28.

Corgosinho P.H.C., Martínez Arbizu P., Santos-Silva E.N. 2007b. Redescription of Remaneicaris ignotus (Dussart, 1983) a Parastenocarididae (Copepoda, Harpacticoida) with an unusual set of plesiomorphic characters // Invertebrate Zoology. Vol.4. No.1. P.31-44.

Corgosinho P.H.C., Martínez Arbizu P., Reid J.W. 2008. Revision of the genus Murunducaris (Copepoda: Harpacticoida: Parastenocarididae), with descriptions of two species from South America // Journal of Crustacean Biology. Vol.28. P.700-720.

Corgosinho P.H.C., Martínez Arbizu P., Santos-Silva E.N. 2010. Revision of Brasilibathynellocaris Jacoby, 1972 (Copepoda: Harpacticoida: Parastenocarididae) with redefinition of the genus // Zoological Journal of the Linnean Society. Vol.159. P.52-66.

Dussart B.H. 1983. Sobre algunos Copépodos de America del Sur. III // Comunicaciones Científicas del CECOAL. Vol.16. P.1-8.

Ferrari F.D., Ivanenko V.N. 2008. The identity of protopodal segments and the ramus of maxilla 2 of copepods (Copepoda) // Crustaceana. Vol.81. P.823-835.

Galassi D.M.P., De Laurentiis P. 2004. Towards a revision of the genus Parastenocaris Kessler, 1913: establishment of Simplicaris gen. nov. from groundwaters in central Italy and review of the $P$. brevipes-group (Copepoda, Harpacticoida, Parastenocarididae)//Zoo- logical Journal of the Linnean Society. Vol.140. P.417436

Glatzel T. 1991. Neue morphologische Aspekte und die Copepodid-Stadien von Parastenocaris phyllura Kiefer (Copepoda, Harpacticoida) // Zoologica Scripta. Vol.20. P.375-393.

Huys R., Boxshall G.A. 1991. Copepod Evolution // Ray Society, London. Vol. 159. P.1-468.

ICZN. 1999. International Code of Zoological Nomenclature. Fourth ed. London: International Trust for Zoological Nomenclature. XXIX $+306 \mathrm{p}$.

Jakobi H. 1972. Trends (Enp. P4 \#) innerhalb der Parastenocarididen (Copepoda, Harpacticoida) // Crustaceana. Vol.22. P.127-146.

Karanovic T. 2004. Subterranean Copepoda from arid Western Australia // Crustaceana Monographs. Vol.3. P.i-viii. 1-366.

Karanovic T. 2005. Two new subterranean Parastenocarididae (Crustacea, Copepoda, Harpacticoida) from Western Australia // Records of the Western Australian Museum. Vol.22. P.353-374.

Kiefer F. 1936. Eine neue Parastenocaris-Art (Crustacea Copepoda) aus Brasilien // Zoologischer Anzeiger. Bd.116. S.142-144.

Kiefer F. 1967. Zwei weitere Parastenocaris-Arten (Copepoda Harpacticoida) aus dem mittleren AmazonasGebiet // Amazoniana. Bd.1. S.131-134.

Lang K. 1948. Monographie der Harpacticiden. Vol I, II (repr. 1975). Lund: Otto Koelz Science Publischer. $1682 \mathrm{p}$.

Martínez Arbizu P., Moura G. 1994. The phylogenetic position of the Cylindropsyllinae Sars (Copepoda, Harpacticoida) and the systematic status of the Leptopontiinae Lang // Zoologische Beitrage, Neue Folge. Bd.35. S.55-77.

Noodt W. 1962. Limnisch-subterrane Copepoden der Gattung Parastenocaris Kessler aus Mittelamerika // Beiträge zur Neotropischen Fauna. Bd.2. S.223-248.

Noodt W. 1963. Subterrane Crustaceen der zentralen Neotropis // Zoologischer Anzeiger. Bd.171. S.114-147.

Noodt W. 1965. Crustacea subterranea aus Argentinien // Beiträge zur Neotropischen Fauna. Bd.4. S.84-129.

Ranga Reddy Y., Schminke H.K. 2009. Discovery of the genus Kinnecaris Jakobi, 1972 (Copepoda, Harpacticoida, Parastenocarididae) in southeastern India, with description of a new species // Crustaceana. Vol.82. P. 311-326

Reid J.W. 1994. Murunducaris juneae, new genus, new species (Copepoda: Harpacticoida: Parastenocarididae) from a wet campo in central Brazil // Journal of Crustacean Biology. Vol.14. P.771-781.

Reid J.W. 1995. Redescription of Parastenocaris brevipes Kessler and description of a new species of Parastenocaris (Copepoda: Harpacticoida: Parastenocarididae) from the U.S.A. // Canadian Journal of Zoology. Vol.73. P.173-187.

Rouch R. 1962. Harpacticoides (Crustaces Copepodes) d'Amérique du Sud // Delamare Debouteville C., Rapoport E. (eds.). Biologie de l'Amérique Australe. Paris: CNRS. P.237-280. 
Schminke H.K. 1976. The ubiquitous telson and the deceptive furca // Crustaceana. Vol.30. P.292-300.

Schminke H.K. 1993. The subfamilies of the Parastenocarididae (Copepoda, Harpacticoida) // Proceedings of the 5th International Conference on Copepoda. Baltimore, Maryland. ****

Schminke H.K. 2008. First report of groundwater fauna from Papua New Guinea: Kinnecaris Jakobi, 1972 redefined (Copepoda, Harpacticoida, Parastenocarididae), and description of a new species // Crustaceana.
Vol.81. P.1241-1253.

Schminke H.K. 2009. Monodicaris gen. n. (Copepoda, Harpacticoida, Parasenocarididae) from West Africa // Crustaceana. Vol.82. P.367-378.

Schminke H.K. 2010. High-level phylogenetic relationships within Parastenocarididae (Crustacea, Copepoda, Harpacticoida)//Crustaceana. Vol.83. No.3.P.343367.

Responsible editors: F.D. Ferrari, V.N. Ivanenko 